\title{
Article \\ Effects of NAA and Ecklonia maxima Extracts on Lettuce and Tomato Transplant Production
}

\author{
Alessandra Moncada (D, Filippo Vetrano, Alessandro Esposito and Alessandro Miceli *(D) \\ Dipartimento di Scienze Agrarie Alimentari e Forestali, Università di Palermo, Viale delle Scienze 4, \\ 90129 Palermo, Italy; alessandra.moncada@unipa.it (A.M.); filippo.vetrano@unipa.it (F.V.); \\ alexesposito1996@libero.it (A.E.) \\ * Correspondence: alessandro.miceli@unipa.it; Tel.: +39-091-238-62229
}

check for updates

Citation: Moncada, A.; Vetrano, F.; Esposito, A.; Miceli, A. Effects of NAA and Ecklonia maxima Extracts on Lettuce and Tomato Transplant Production. Agronomy 2022, 12, 329 https://doi.org/10.3390/ agronomy12020329

Academic Editor: Yoshiharu Fujii

Received: 30 December 2021

Accepted: 25 January 2022

Published: 27 January 2022

Publisher's Note: MDPI stays neutral with regard to jurisdictional claims in published maps and institutional affiliations.

Copyright: (C) 2022 by the authors. Licensee MDPI, Basel, Switzerland. This article is an open access article distributed under the terms and conditions of the Creative Commons Attribution (CC BY) license (https:// creativecommons.org/licenses/by/ $4.0 /)$.

\begin{abstract}
Ecklonia maxima and the commercial biostimulants produced from it contain various plant growth regulators that are responsible for the growth stimulation recorded in many crops. Auxins are one of the major plant growth regulators contained in E. maxima extracts. The aim of this research was to evaluate the growth-promoting effect of a seaweed extract from E. maxima on lettuce and tomato transplant production under nursery conditions, and to compare the effect of this extract with an equal concentration of synthetic auxin. Two doses of natural or synthetic exogenous auxins (50 or $100 \mu \mathrm{g} \mathrm{L}^{-1}$ ) were supplied to the substrate through the irrigation water with an ebb and flow system, 4,11 , and 18 days after sowing. A commercial biostimulant based on E. maxima extract was used as a source of natural auxin, while 1-naphthaleneacetic acid (NAA) was used as a synthetic auxin. Seedlings supplied only with water were used as a control. Tomato seedlings treated with $100 \mu \mathrm{g} \mathrm{L}^{-1}$ of natural auxins from E. maxima extract produced the tallest plants $(+22 \%)$, with a higher leaf number $(+12 \%)$, a wider leaf area $(+44 \%)$, and a stronger stem $(+12 \%)$, whereas lettuce seedling growth was promoted by all the treatments, but with a greater effect with increasing auxin supplementation and when using E. maxima extract, compared to NAA. The results showed that the supplementation of exogenous synthetic auxin (NAA), or an E. maxima extract containing natural auxins, can have a growth-promoting effect on lettuce and tomato seedlings. This effect was more evident on lettuce than tomato. The biostimulant produced from E. maxima extracts improved seedling quality and promoted shoot and root growth more than the NAA used as a synthetic source of auxins.
\end{abstract}

Keywords: vegetable nursery; seedling; Solanum lycopersicum; Lactuca sativa; seaweed extract; synthetic auxins; natural auxins; biostimulants

\section{Introduction}

One of the main goals of vegetable nurseries is to produce high-quality transplants in a short time. Transplants are commonly used for establishing crops in open fields and under greenhouses in many countries of the world [1], as they may determine many advantages during crop growth and improve vegetable production [2-5]. These benefits can be closely related to the management of the seedlings during early growth (irrigation, fertilization, climatic conditions) [1,6-9] and their quality characteristics (e.g., height, leaf number and area, dry matter content). Nursery growers adopt intensive cultivation systems with daily applications of water and fertilizers for enhancing the seedling growth rate that may affect the sustainability of the vegetable nursery industry. Vegetable seedlings are generally raised in trays filled with a limited volume of substrates with low nutrient content. In these conditions, fertilization allows the shortening of production time and the production of good quality transplants that can guarantee a good performance after transplanting. The use of fertilizers on plants raised in containers with limited volumes of substrates, subjected to daily irrigation, can have a negative impact on the environment [10].

The aim to improve the sustainability of intensive agriculture systems is pulling toward the reduction of synthetic inputs and their substitution with natural resources. 
This approach needs a broad knowledge of the mechanisms underlying plant growth and development that are very complex and not yet fully understood. These mechanisms can have a crucial role in the strategies for enhancing crop yield in sustainable ways through the limitation of the use of chemical fertilizers or other synthetic products.

Growth-promoting products or microbes have been used for increasing crop production and sustainability and reducing the need for chemical inputs [11]. Plant growth promoters, also known as biostimulants [12], have different functions (biofertilizers, biocontrol, phytostimulation, etc.) $[13,14]$ and are of different types (bacteria, mycorrhizae, humic acid, algae extracts, etc.).

Algae or seaweed extracts are often produced from brown algae (Phaeophyceae) [15] and are sold in liquid form as commercial biostimulants. They can increase nutrient uptake, resistance to biotic and abiotic stresses, and improve seed germination and crop yield [16]. Seaweed extracts contain appreciable quantities of the macroelements $\mathrm{Ca}$, $\mathrm{Mg}, \mathrm{K}, \mathrm{Na}, \mathrm{P}$, and $\mathrm{S}$, as well as some trace elements, including Fe $[17,18]$. Recently, they were reported to also include considerable amounts of polyamines [19], abscisic acid, and brassinosteroids $[20,21]$. Seaweed extract contains several osmoprotectants, such as the quaternary ammonium compounds betaine and proline, together with mannitol (a common storage sugar-alcohol) [22,23]. Alginates and polysaccharides [23,24] are other components of great biological interest for their reported stimulation of nutrient uptake, translocation, and ability to stimulate root growth [22]. In addition, seaweed extracts also contain many types of hormone-like biologically active molecules [25], such as auxins, cytokinins, ethylene, and gibberellins [26,27]. The content of auxins and cytokinins in seaweed extract was found to be similar to those of turgid leaves of higher plants [17].

Ecklonia maxima (Osbeck) Papenfuss is a brown algae seaweed native to the southern oceans, mainly found along the southern Atlantic coast of Africa. It has been harvested over the last years to produce alginate, animal feed, fertilizers, and plant biostimulants [28]. The commercial extracts of this seaweed have been used for growth-promoting effects on adult plants of many crops [29,30], but little is known on their effects at early growth stages. E. maxima and the commercial biostimulants produced from it contain various plant growth regulators (auxins, cytokinins, polyamines, gibberellins, abscisic acid, and brassinosteroids) that are responsible for the growth stimulation recorded on many crops [21,31,32]. The auxins are one of the major plant growth regulators contained in some commercial E. maxima extracts, such as Basfoliar ${ }^{\circledR}$ Kelp SL, which is obtained by gentle mechanical extraction from fresh seaweed and contains $0.2 \% \mathrm{~N}, 1.5 \% \mathrm{P}_{2} \mathrm{O}_{5}, 0.03 \% \mathrm{~K}_{2} \mathrm{O}, 11 \mathrm{mg} \mathrm{L}^{-1}$ of auxins of vegetal origin and amino acids, carbohydrates, proteins, minerals, and trace of cytokinins $(0.04 \%)[33,34]$.

The mechanisms responsible for the growth-promoting effect of seaweed extract are not yet well known. Understanding their mode of action is highly complicated due to the multiple interactions among the several bioactive compounds within the same extract [35]. Nevertheless, their effects on plant growth, development, and yield are similar to the physiological responses recorded in crop plants treated with plant growth regulators $[12,16,36]$. Thus, it could be hypothesized that the effects on plants of a seaweed extract containing natural phytohormones could be similar to those determined by the application of an equal concentration of exogenous synthetic plant growth regulators.

A wide range of processes influencing vegetable crop development and growth can be controlled by exogenous auxins $[14,37,38]$. These effects may vary according to the treated species, plant age, and doses applied [37,39-41].

Among vegetable crops, lettuce and tomato are widely cultivated under different latitudes and conditions (open field or protected cultivation) throughout the year. Lettuce and tomato transplants are produced in very large numbers by nursery industries all year long; thus, there is a growing interest in using biostimulants or plant growth regulators to increase nursery industry sustainability.

Therefore, the aim of the research was to evaluate the growth-promoting effect of a seaweed extract from E. maxima containing natural auxins on lettuce and tomato transplant 
production, and to compare the effect of this extract with an equal concentration of a synthetic source of auxins to investigate a possible mode of action of the seaweed extract.

\section{Materials and Methods}

\subsection{Growth Conditions}

The effects of synthetic and natural auxin treatments on transplant production were evaluated in a nursery trial carried out under commercial conditions in a greenhouse situated at the Department of Agricultural, Food, and Forest Sciences (SAAF-University of Palermo, Italy) ( $38^{\circ} 6^{\prime} 28^{\prime \prime} \mathrm{N} 13^{\circ} 21^{\prime} 3^{\prime \prime} \mathrm{E}$; altitude $49 \mathrm{~m}$ above sea level) during autumn 2021. During the crop cycle, the temperature and the relative humidity of the air inside the greenhouse were monitored using a data logger (mod. 608-H1, Testo s.p.a., Settimo M.se, Italy). A pyranometer (SR30-L, Campbel Scientific, Loughborough, UK) was used for solar radiation measurements. During the experiment, the average temperature outside the greenhouse ranged between $16.5 \pm 0.4{ }^{\circ} \mathrm{C}$ (night) and $23.4 \pm 0.5^{\circ} \mathrm{C}$ (day), and the average net solar radiation at noon was $451 \mathrm{~W} \cdot \mathrm{m}^{-2}$, with a day length that ranged between 9 and $10 \mathrm{~h}$. Inside the greenhouse, the air temperature was on average $24.6 \pm 1.2{ }^{\circ} \mathrm{C}$, and ranged between $38.1^{\circ} \mathrm{C}$ (day) and $13.1^{\circ} \mathrm{C}$ (night) (Figure 1), whereas the relative humidity was $84.8 \pm 1.5 \%$ on average, and ranged between $68.2 \%$ and $100 \%$; the light intensity at noon was $41,839 \pm 2451$ lux and ranged from 64,661 to 6097 lux as a function of the cloudiness.

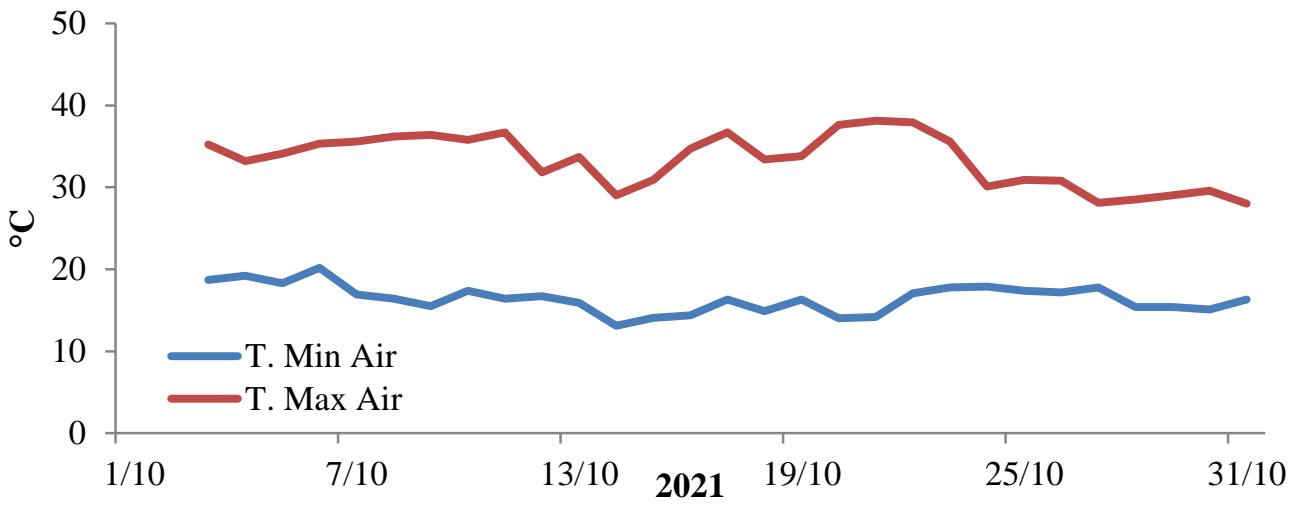

Figure 1. Daily average maximum and minimum temperatures of the air inside the greenhouse during seedlings growth.

\subsection{Transplant Production and Morpho-Physiological Parameter Assessment}

Seeds of Solanum lycopersicum 'Marmande' (Vilmorin, La Ménitré, France) and Lactuca sativa L. 'Meraviglia d'inverno' (Blumen, Piacenza, Italy) were sown into polystyrene trays (104 cells for tomato and 160 for lettuce) filled with a commercial peat substrate (Utilis, GreenView srl, Crocetta del Montello, Italy, containing $800 \mathrm{~g} \mathrm{~m}^{-3}$ of a mineral fertilizer NPK 12-11-18). After sowing (1 October 2021), the trays were kept in a dark room at $25^{\circ} \mathrm{C}$ until seed germination, and were then moved onto fixed benches in the cold greenhouse for seedling growth.

Plantlet emergence occurred 2 and 4 days after sowing for lettuce and tomato, respectively.

Two doses of natural or synthetic exogenous auxins (50 and $100 \mu \mathrm{g} \mathrm{L}^{-1}$ ) were supplied to the substrate through the irrigation water with an ebb and flow system 4, 11, and 18 days after sowing $(09,11$, and 13th $\mathrm{BBCH}$ lettuce and tomato growth stage, respectively). Seedlings supplied only with water were evaluated as control. 1-naphthaleneacetic acid (NAA; Rigenal P PFnPE VAR 5, Cifo srl, Bologna, Italy) was used as a synthetic auxin, while the source of natural auxins was a commercial extract of Ecklonia maxima (Basfoliar ${ }^{\circledR}$ Kelp SL, Compo Expert, Münster, Germany [34]). The two doses of natural auxins corresponded to 4.55 or $9.10 \mathrm{~mL} \mathrm{~L}^{-1} \mathrm{H}_{2} \mathrm{O}$ of the commercial biostimulant $\left(11 \mathrm{mg} \mathrm{L}^{-1}\right.$ of auxins is the content of auxins of vegetal origin declared in the product label). During seedling growth, plants were fertilized by sub-fertigating all the trays (including control) with a nutrient solution with $2 \mathrm{~g} \mathrm{~L}^{-1}$ of a water-soluble NPK fertilizer (20-20-20) after 14 days from sowing. 
The seedlings were sub-irrigated as needed, until they were ready for transplant (on average twice a week).

Plant water use and plant water-use efficiency were calculated from the amount of water consumed by the seedlings for each irrigation and fertigation event by weighing each tray with a digital balance, before refilling the reservoir and after drainage of the exceeding water. Then, plant water use (PWU) was calculated as PWU $\left(\mathrm{g} \mathrm{fw} \mathrm{L}^{-1} \mathrm{H}_{2} \mathrm{O}\right)=$ plant fresh weight $(\mathrm{g}) / \mathrm{H}_{2} \mathrm{O}(\mathrm{L})$, and plant water-use efficiency (WUE) was calculated as WUE $\left(\mathrm{g} \mathrm{dw} \mathrm{L}^{-1} \mathrm{H}_{2} \mathrm{O}\right)$ = plant dry weight $(\mathrm{g}) / \mathrm{H}_{2} \mathrm{O}$ (L) [11]. The total $\mathrm{N}$ consumed during the crop cycle was estimated from the volume of nutrient solution supplied to the seedlings, and the nitrogen-use efficiency [42] was calculated as NUE ( $\left.\mathrm{g} \mathrm{dw} \mathrm{g}^{-1} \mathrm{~N}\right)=$ plant total dry weight $(\mathrm{g}) / \mathrm{N}$ supplied $(\mathrm{g})$.

Leaf stomatal conductance was measured one week before seedlings were ready for transplanting, using a diffusion porometer (AP4, Delta-T Devices Ltd., Cambridge, England) on two young unshaded leaves of 25 seedlings for each species and each replicate.

Leaf color of each seedling was measured on the upper part of 2 randomly selected leaves, using a colorimeter (CR-400, Minolta corporation, Ltd., Osaka, Japan) that measured $L^{*}$ (lightness), $a^{*}$ (positive values for reddish colors and negative values for greenish colors) and $b^{*}$ (positive values for yellowish colors and negative values for bluish colors). These components were used to calculate hue angle $\left(\mathrm{h}^{\circ}\right)$ and chroma $\left(\mathrm{C}^{*}\right)$ as $\mathrm{h}^{\circ}=180^{\circ}+\arctan \left(\mathrm{b}^{*} / \mathrm{a}^{*}\right)[43]$ and $\mathrm{C}^{*}=\left(\mathrm{a}^{* 2}+\mathrm{b}^{* 2}\right)^{1 / 2}$.

About one month after sowing (26 and 25 days for lettuce and tomato, respectively) the seedlings were ready to be transplanted (15-16th and 14-15th BBCH growth stage for lettuce and tomato, respectively) and were destructively sampled for the data collecting.

Four replicated samples of 25 seedlings for each species and each treatment were randomly selected and analyzed to evaluate their morphological characteristics (plant height, stem thickness, leaf number). The leaves were detached from the stem and scanned at 300 dpi (Epson Perfection 4180 Photo, Seiko Epson Corp., Suwa, Japan) to obtain digital images that were analyzed with the ImageJ 1.52a software (National Institutes Health, Bethesda, MD, USA) to measure the leaf area.

Leaves, stem, and roots were weighed and dried to a constant weight at $85{ }^{\circ} \mathrm{C}$ to determine the fresh and dry biomass and the shoot/root ratio for both fresh and dry weight. The specific leaf area (SLA cm $\mathrm{g}^{-1} \mathrm{dw}$ ) was estimated as the leaf area/leaf dry weight.

\subsection{Statistics and Principal Component Analysis}

The experimental design consisted of four replicated samples of 25 seedlings each for every species and every treatment, randomly assigned in four blocks. A one-way ANOVA was performed to evaluate the effects of natural and synthetic auxin treatments on each species. The mean values were compared by the Tukey test at $p \leq 5 \%$ to identify the significant differences among treatments.

All the parameters evaluated in lettuce and tomato seedlings were also used to perform a principal component analysis to investigate the parameters that could effectively discriminate among treatments. The parameters used in the analysis consisted of height, stem diameter, total, leaf, stem, and root fresh and dry weight, shoot/root ratio of fresh and dry weights, dry matter percentage, leaf number, plant and leaf area, SLA, stomatal conductance, PWU, WUE, NUE, $\mathrm{L}^{*}$, chroma, and hue angle). The principal components (PCs) were assessed by holding only the factors with eigenvalues higher than 1.0. The plot of the PCs allowed us to study the correlations between the variables of the input data set, and the initial 24 variables were projected into the subspace defined by the first and second PCs, and correlated variables were revealed. The statistical tests, such as homoscedasticity and normality, ANOVA, and PCA, were performed using SPSS version 13.0 (SPSS Inc., Chicago, IL, USA). 


\section{Results}

\subsection{Morphophysiological Parameters of Lettuce Seedlings}

The use of synthetic auxin (NAA) or the algae extract from Basfoliar ${ }^{\circledR}$ Kelp SL (AE) containing natural auxins had significant effects on many morphological and physiological parameters.

The height of the control seedlings was $10.5 \mathrm{~cm}$, and was significantly increased by AE treatments (from seaweed extract) and by $100 \mu \mathrm{g} \mathrm{L}^{-1} \mathrm{NAA}(12.7 \mathrm{~cm}$ on average) (Table 1 , Figure 2A). The stem diameter of the treated seedlings was significantly thicker $(+19.8 \%)$ than the control $(2.92 \mathrm{~mm})$. The treated seedlings also had a higher leaf number than the control but differed in leaf size.

The greatest leaf area $\left(79.4 \mathrm{~cm}^{2}\right.$ seedling ${ }^{-1} ; 13.3 \mathrm{~cm}^{2}$ leaf $\left.{ }^{-1}\right)$ was measured in lettuce seedlings treated with $50 \mu \mathrm{g} \mathrm{L}^{-1}$ AE that did not significantly differ from those treated with $100 \mu \mathrm{g} \mathrm{L}^{-1} \mathrm{AE}$; treatments with NAA also increased the leaf area $(+29.2 \%$ and $+21.8 \%$ on average for seedling and leaf area, respectively) compared to the control $\left(54.2 \mathrm{~cm}^{2}\right.$ seedling ${ }^{-1}$; $9.6 \mathrm{~cm}^{2}$ leaf $^{-1}$ ), but to a lower extent than AE (Table 1, Figure 2B). The specific leaf area was negatively affected in the seedlings treated with $50 \mu \mathrm{g} \mathrm{L}^{-1}$ of NAA.

The chromatic characteristics of lettuce leaves $\left(\mathrm{L}^{*}\right.$, chroma and hue) were only slightly influenced by the treatments. The leaf color was found to be significantly lighter than the control in the lettuce seedlings treated with $50 \mu \mathrm{g} \mathrm{L}^{-1} \mathrm{AE}$ or NAA, but they showed no significant change in chroma and hue angle (Table 1).
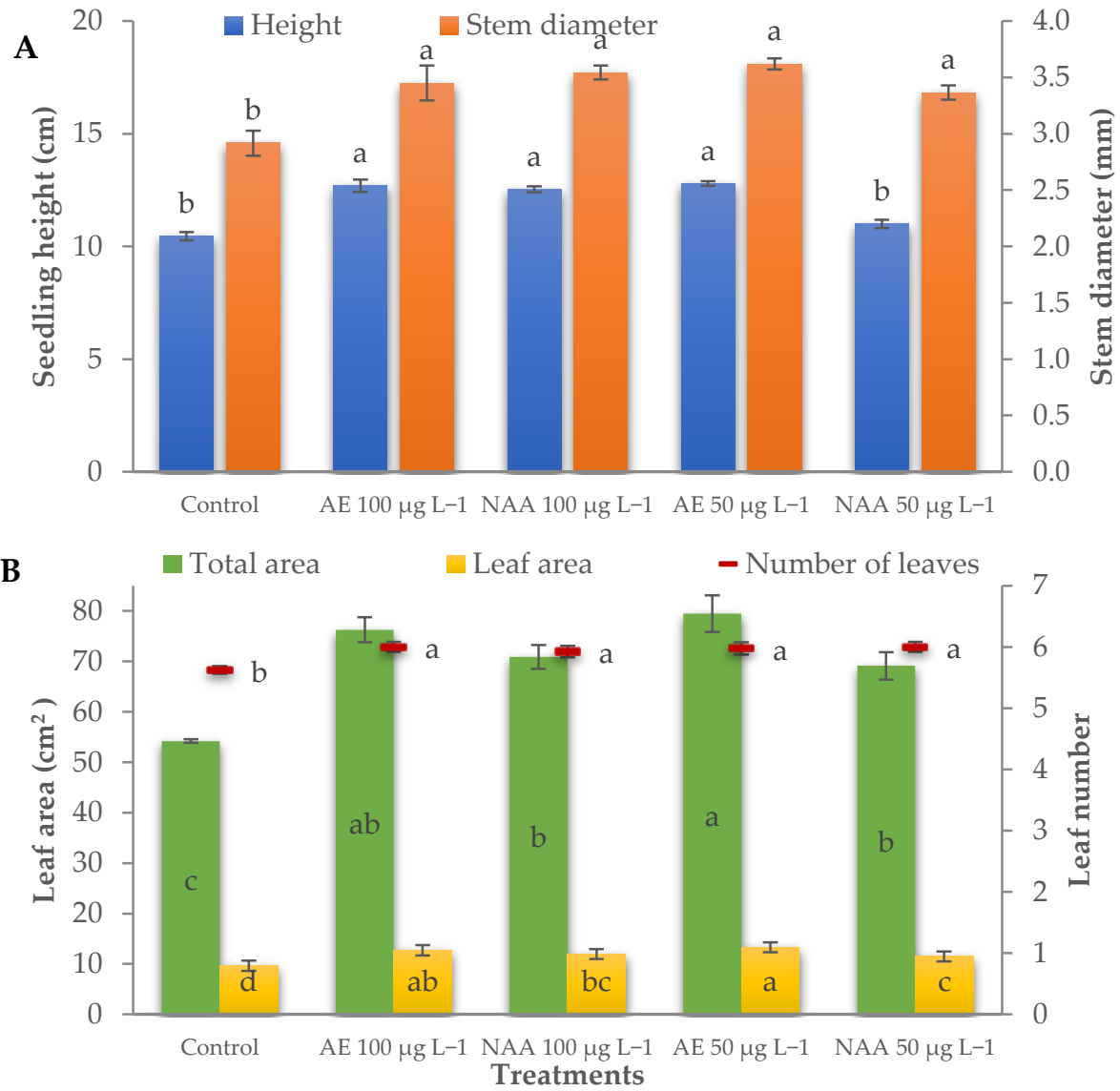

Figure 2. Effect of different doses $\left(50 \mu \mathrm{g} \mathrm{L}^{-1}\right.$ or $\left.100 \mu \mathrm{g} \mathrm{L}^{-1}\right)$ of natural (AE-algae extract from Ecklonia maxima) and synthetic (NAA) exogenous auxins on seedling height and stem diameter (A), and on total seedling area, leaf area, and leaf number (B) of lettuce transplants (bars represent standard errors of the means; points or bars of the same color with different letters are significantly different at $p<0.05$ according to the Tukey test). 
Table 1. Effect of different doses $\left(50 \mu \mathrm{g} \mathrm{L}^{-1}\right.$ or $\left.100 \mu \mathrm{g} \mathrm{L}^{-1}\right)$ of natural (AE-algae extract from Ecklonia maxima) and synthetic (NAA) exogenous auxins on morphological parameters and chromatic characteristics of lettuce transplants.

\begin{tabular}{|c|c|c|c|c|c|c|c|c|c|}
\hline Treatments & $\begin{array}{l}\text { Height } \\
\text { (cm) }\end{array}$ & $\begin{array}{c}\text { Stem } \\
\text { Diameter } \\
(\mathrm{mm})\end{array}$ & $\begin{array}{l}\text { Number } \\
\text { of Leaves }\end{array}$ & $\begin{array}{l}\text { Leaf Area } \\
\left(\mathrm{cm}^{2}\right. \\
\left.\text { seedling }^{-1}\right)\end{array}$ & $\begin{array}{c}\text { Leaf Area } \\
\left(\mathrm{cm}^{2} \text { leaf }^{-1}\right)\end{array}$ & $\begin{array}{l}\operatorname{SLA}\left(\mathrm{cm}^{2}\right. \\
\left.\mathrm{g} \mathrm{dw}^{-1}\right)\end{array}$ & $\mathbf{L}^{*}$ & Chroma & Hue \\
\hline Control & $\mathrm{z} 10.5 \mathrm{~b}$ & $2.92 \mathrm{~b}$ & $5.63 \mathrm{~b}$ & $54.2 \mathrm{c}$ & $9.6 \mathrm{~d}$ & $1247.6 \mathrm{a}$ & $55.9 \mathrm{a}$ & 43.3 & 120.2 \\
\hline $\mathrm{AE} 100 \mu \mathrm{g} \mathrm{L}^{-1}$ & $12.7 \mathrm{a}$ & $3.45 \mathrm{a}$ & $6.00 \mathrm{a}$ & $76.2 \mathrm{ab}$ & $12.7 \mathrm{ab}$ & $1222.4 \mathrm{a}$ & $55.4 \mathrm{ab}$ & 43.2 & 120.5 \\
\hline NAA $100 \mu \mathrm{g} \mathrm{L}^{-1}$ & $12.5 \mathrm{a}$ & $3.54 \mathrm{a}$ & $5.93 \mathrm{a}$ & $70.9 \mathrm{~b}$ & $12.0 \mathrm{bc}$ & $1178.1 \mathrm{a}$ & $55.3 \mathrm{ab}$ & 43.2 & 120.3 \\
\hline AE $50 \mu \mathrm{g} \mathrm{L}^{-1}$ & $12.8 \mathrm{a}$ & $3.62 \mathrm{a}$ & $5.98 \mathrm{a}$ & $79.4 \mathrm{a}$ & $13.3 \mathrm{a}$ & $1195.9 \mathrm{a}$ & $54.6 \mathrm{~b}$ & 43.5 & 120.2 \\
\hline NAA $50 \mu \mathrm{g} \mathrm{L}^{-1}$ & $11.0 \mathrm{~b}$ & $3.36 \mathrm{a}$ & $6.00 \mathrm{a}$ & $69.1 \mathrm{~b}$ & $11.5 \mathrm{c}$ & $1044.3 \mathrm{~b}$ & $54.4 \mathrm{~b}$ & 44.1 & 120.7 \\
\hline Significance $\mathrm{x}$ & $* * *$ & $* * *$ & * & $* * *$ & $* * *$ & $* * *$ & $*$ & ns & ns \\
\hline
\end{tabular}

${ }^{\mathrm{z}}$ Each value is the mean of 4 replicated samples of 25 seedlings each. Data within a column followed by the same letters do not differ significantly at $p \leq 0.05$ according to the Tukey test. ${ }^{\times}$Significance: $\mathrm{ns}=$ not significant; * significant at $p<0.05 ; * * *$ significant at $p<0.001$.

The total fresh weight (fw) of the control seedling was $1.19 \mathrm{~g} \mathrm{fw}$ seedlings ${ }^{-1}$ (Table 2, Figure 3). The treatments determined an increase in total fresh weight by $46.6 \%$ on average, when E. maxima extracts or $100 \mu \mathrm{g} \mathrm{L}^{-1}$ of NAA were supplemented to the seedlings, and by $34.4 \%$ with $50 \mu \mathrm{g} \mathrm{L}^{-1}$ of NAA.

Table 2. Effect of different doses $\left(50 \mu \mathrm{g} \mathrm{L}^{-1}\right.$ or $100 \mu \mathrm{g} \mathrm{L}-1$ ) of natural (AE-algae extract from Ecklonia maxima) and synthetic (NAA) exogenous auxins on the fresh and dry weight of lettuce transplants.

\begin{tabular}{|c|c|c|c|c|c|c|c|c|c|c|c|}
\hline \multirow{2}{*}{ Treatments } & \multicolumn{5}{|c|}{ Fresh Weight (g seedling ${ }^{-1}$ ) } & \multicolumn{5}{|c|}{ Dry Weight (mg seedling ${ }^{-1}$ ) } & \multirow{2}{*}{ Dry Matter \% } \\
\hline & Total & Leaves & Stem & Root & Shoot/Root & Total & Leaves & Stem & Root & Shoot/Root & \\
\hline Control & $\mathrm{z} 1.19 \mathrm{c}$ & $0.99 \mathrm{~d}$ & $0.12 \mathrm{~b}$ & $0.09 \mathrm{~b}$ & $12.9 \mathrm{c}$ & $61.3 \mathrm{~b}$ & $43.5 \mathrm{~b}$ & 4.5 & $13.3 \mathrm{a}$ & $3.6 \mathrm{c}$ & $5.2 \mathrm{a}$ \\
\hline $\mathrm{AE} 100 \mu \mathrm{g} \mathrm{L}^{-1}$ & $1.75 \mathrm{a}$ & $1.50 \mathrm{ab}$ & $0.16 \mathrm{a}$ & $0.10 \mathrm{~b}$ & $17.5 \mathrm{~b}$ & $77.7 \mathrm{a}$ & $62.5 \mathrm{a}$ & 4.5 & $10.7 \mathrm{~b}$ & $6.3 \mathrm{~b}$ & $4.4 \mathrm{~b}$ \\
\hline NAA $100 \mu \mathrm{g} \mathrm{L}^{-1}$ & $1.71 \mathrm{a}$ & $1.42 \mathrm{bc}$ & $0.16 \mathrm{a}$ & $0.13 \mathrm{a}$ & $12.1 \mathrm{c}$ & $72.5 \mathrm{a}$ & $60.3 \mathrm{a}$ & 4.8 & $7.5 \mathrm{c}$ & $8.7 \mathrm{a}$ & $4.2 \mathrm{~b}$ \\
\hline AE $50 \mu \mathrm{g} \mathrm{L}^{-1}$ & $1.78 \mathrm{a}$ & $1.53 \mathrm{a}$ & $0.17 \mathrm{a}$ & $0.08 \mathrm{~b}$ & $21.4 \mathrm{a}$ & $80.2 \mathrm{a}$ & $66.4 \mathrm{a}$ & 4.5 & $9.3 \mathrm{bc}$ & $7.8 \mathrm{ab}$ & $4.5 \mathrm{~b}$ \\
\hline NAA $50 \mu \mathrm{g} \mathrm{L}^{-1}$ & $1.60 \mathrm{~b}$ & $1.38 \mathrm{c}$ & $0.13 \mathrm{~b}$ & $0.09 \mathrm{~b}$ & $17.4 \mathrm{~b}$ & $80.8 \mathrm{a}$ & $66.1 \mathrm{a}$ & 4.7 & $10.0 \mathrm{~b}$ & $7.3 \mathrm{ab}$ & $5.1 \mathrm{a}$ \\
\hline Significance ${ }^{\mathrm{x}}$ & $* * *$ & $* * *$ & $* * *$ & $* * *$ & $* * *$ & $* * *$ & $* * *$ & ns & $* * *$ & $* * *$ & $* * *$ \\
\hline
\end{tabular}

${ }^{\mathrm{z}}$ Each value is the mean of 4 replicated samples of 25 seedlings each. Data within a column followed by the same letters do not differ significantly at $p \leq 0.05$ according to Tukey test. ${ }^{\times}$Significance: ns $=$not significant; $* * *$ significant at $p<0.001$. All percentage data were subjected to angular transformation.

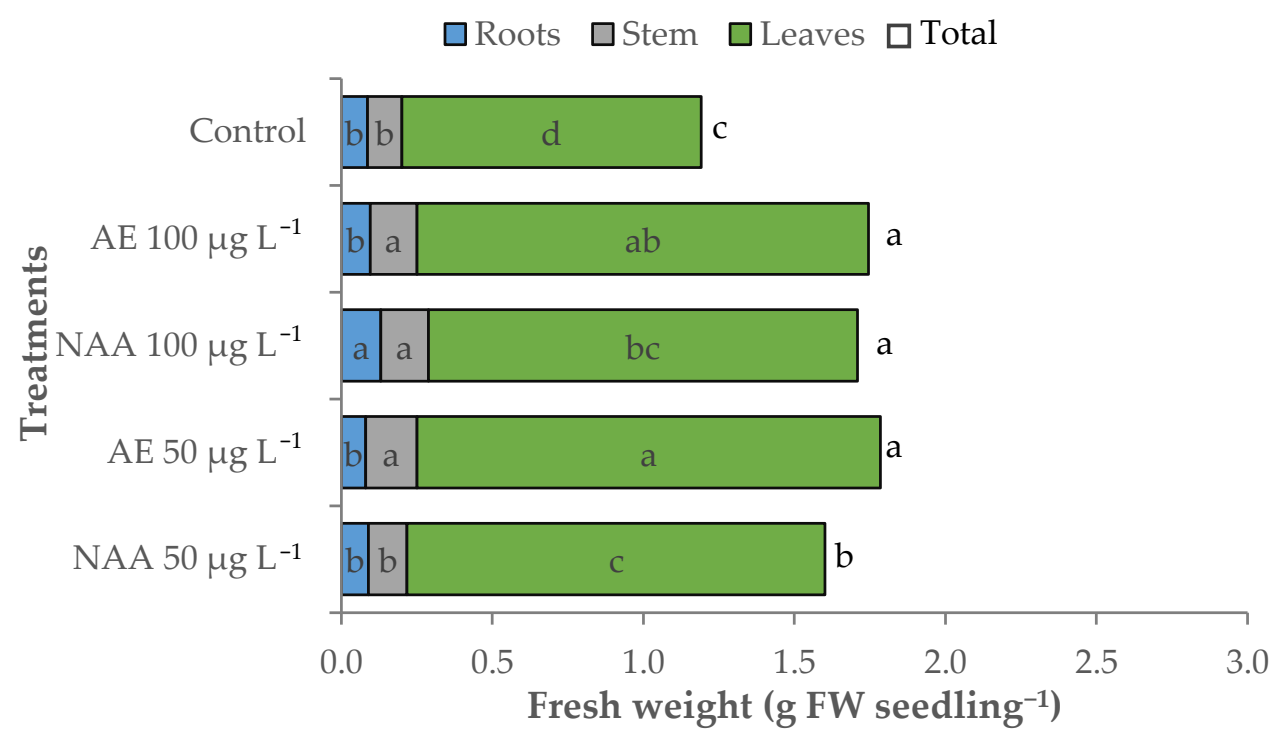

Figure 3. Effect of different doses $\left(50 \mu \mathrm{g} \mathrm{L}^{-1}\right.$ or $\left.100 \mu \mathrm{g} \mathrm{L}^{-1}\right)$ of natural (AE-algae extract from Ecklonia maxima) or synthetic (NAA) exogenous auxins on the total, root, stem, and leaves fresh biomass of lettuce transplants (bars of the same color with different letters are significantly different at $p<0.05$ according to the Tukey test). 
These differences were mainly due to the leaf weight that recorded greater variations compared to the stem and root fresh weight (Table 2, Figure 3). The seedlings with the highest amount of leaves in terms of fresh weight were those treated with both doses of algae extract (1.53 and $1.50 \mathrm{~g}$ fw seedling ${ }^{-1}$, respectively), whereas the lowest leaf fresh biomass was recorded in the control seedlings $\left(0.99 \mathrm{~g} \mathrm{fw}\right.$ seedling $\left.{ }^{-1}\right)$; intermediate values were observed with NAA treatments. The effect of treatments on fresh biomass partitioning was highlighted by the shoot/root ratio of the fresh weight, which increased up to 21.4 with $50 \mu \mathrm{g} \mathrm{L}^{-1}$ of natural auxins (AE) and to 17.5 on average with $100 \mu \mathrm{g} \mathrm{L}^{-1} \mathrm{AE}$ or $50 \mu \mathrm{g} \mathrm{L}^{-1}$ of NAA (Table 2).

The total dry biomass accumulated in control seedlings was $61.3 \mathrm{mg} \mathrm{dw}$ seedling ${ }^{-1}$ and was significantly increased by all the treatments (+26.9\% on average) (Table 2, Figure 4 ). A similar trend was recorded for leaf dry weight, while root dry weight was significantly reduced by the treatments, especially with $100 \mu \mathrm{g} \mathrm{L}^{-1}$ of NAA $(-43.5 \%)$. The dry matter percentage of lettuce seedlings was significantly lowered by the treatments $(4.3 \%$ on average), except for the treatment with $50 \mu \mathrm{g} \mathrm{L}^{-1}$ of NAA (Table 2).

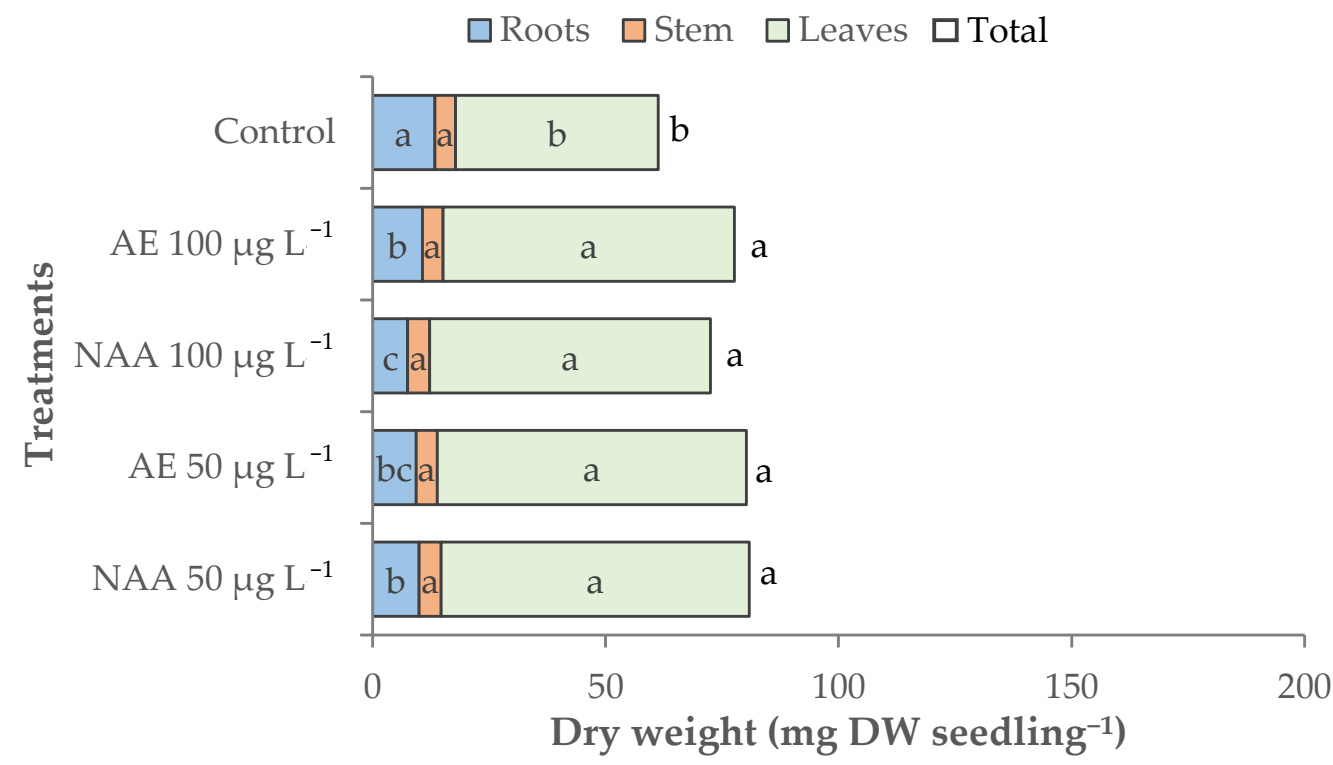

Figure 4. Effect of different doses $\left(50 \mu \mathrm{g} \mathrm{L}^{-1}\right.$ or $\left.100 \mu \mathrm{g} \mathrm{L}^{-1}\right)$ of natural (AE-algae extract from Ecklonia maxima) or synthetic (NAA) exogenous auxins on the total, root, stem, and leaves dry biomass of lettuce transplants (bars of the same color with different letters are significantly different at $p<0.05$ according to the Tukey test).

Only a high concentration $\left(100 \mu \mathrm{g} \mathrm{L}^{-1}\right)$ of natural (AE) and synthetic (NAA) auxins was effective in increasing the stomatal conductance of the leaves $\left(885.3 \mathrm{mmol} \mathrm{m} \mathrm{s}^{-1}\right.$, on average) while the other treatments did not differ from the control $\left(328.8 \mathrm{mmol} \mathrm{m}^{2} \mathrm{~s}^{-1}\right)$ (Table 3).

Control seedlings produced $44.0 \mathrm{~g}$ of fresh weight per liter of irrigation water (PWU) and did not differ significantly from the seedlings treated with $50 \mu \mathrm{g} \mathrm{L}^{-1}$ of NAA. The use of $100 \mu \mathrm{g} \mathrm{L}^{-1} \mathrm{AE}$ increased the plant water use by $26.9 \%$ compared to control, while $100 \mu \mathrm{g} \mathrm{L}^{-1}$ of NAA and $50 \mu \mathrm{g} \mathrm{L}^{-1}$ of natural auxins (AE) raised PWU by $14.5 \%$ on average (Table 3). No significant effect was recorded on the water use efficiency that was $2.3 \mathrm{~g} \mathrm{dw} \mathrm{L} \mathrm{L}^{-1} \mathrm{H}_{2} \mathrm{O}$, on average. Small modifications were also found in nitrogen-use efficiency: $11.3 \mathrm{~g} \mathrm{dw}^{-1} \mathrm{~N}$ in the control seedlings, which increased significantly $(+14.8 \%)$ only with $100 \mu \mathrm{g} \mathrm{L}^{-1} \mathrm{AE}$. 
Table 3. Effect of different doses $\left(50 \mu \mathrm{g} \mathrm{L}^{-1}\right.$ or $100 \mu \mathrm{g} \mathrm{L}-1$ ) of natural (AE-algae extract from Ecklonia maxima) and synthetic (NAA) exogenous auxins on stomatal conductance, plant water use (PWU), water-use efficiency (WUE), and nitrogen-use efficiency (NUE) of lettuce transplants.

\begin{tabular}{|c|c|c|c|c|}
\hline Treatments & $\begin{array}{c}\text { Stomatal } \\
\text { Conductance } \\
\left(\mathrm{mmol} \mathrm{m}^{2} \mathrm{~s}^{-1}\right)\end{array}$ & $\begin{array}{c}\text { PWU } \\
\left(\mathrm{g} \mathrm{fw} \mathrm{L} \mathrm{L}^{-1} \mathrm{H}_{2} \mathrm{O}\right)\end{array}$ & 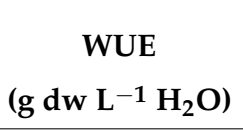 & $\begin{array}{c}\text { NUE } \\
\left(\mathrm{g} \mathrm{dw}^{-1} \mathrm{~N}\right)\end{array}$ \\
\hline Control & $\mathrm{z} 328.8 \mathrm{~b}$ & $44.0 \mathrm{c}$ & 2.3 & $11.3 \mathrm{~b}$ \\
\hline $\mathrm{AE} 100 \mu \mathrm{g} \mathrm{L}^{-1}$ & $903.0 \mathrm{a}$ & $55.8 \mathrm{a}$ & 2.5 & $13.0 \mathrm{a}$ \\
\hline NAA $100 \mu \mathrm{g} \mathrm{L}^{-1}$ & $867.5 \mathrm{a}$ & $51.4 \mathrm{~b}$ & 2.2 & $11.7 \mathrm{ab}$ \\
\hline AE $50 \mu \mathrm{g} \mathrm{L}^{-1}$ & $481.0 \mathrm{~b}$ & $49.3 \mathrm{~b}$ & 2.2 & $12.1 \mathrm{ab}$ \\
\hline NAA $50 \mu \mathrm{g} \mathrm{L}^{-1}$ & $537.0 \mathrm{~b}$ & $45.2 \mathrm{c}$ & 2.3 & $12.4 \mathrm{ab}$ \\
\hline Significance $^{\mathrm{x}}$ & $* * *$ & $* * *$ & ns & * \\
\hline
\end{tabular}

${ }^{\mathrm{z}}$ Each value is the mean of 4 replicated samples of 25 seedlings each. Data within a column followed by the same letters do not differ significantly at $p \leq 0.05$ according to Tukey test. ${ }^{\times}$Significance: ns $=$not significant; * significant at $p<0.05 ; * * *$ significant at $p<0.001$.

\subsection{Morphophysiological Parameters of Tomato Seedlings}

All the morphological parameters were influenced by the treatments. The height of the plants was higher than the control $(15.5 \mathrm{~cm})$ only with the use of $100 \mu \mathrm{g} \mathrm{L}^{-1}$ of natural auxins from $\mathrm{AE}(+22.2 \%)$ (Table 4, Figure $5 \mathrm{~A})$, which also determined the thickest stem $(2.93 \mathrm{~mm})$. A significant increase in stem diameter compared to control $(2.62 \mathrm{~mm})$ was also found in the seedling treated with $100 \mu \mathrm{g} \mathrm{L}{ }^{-1}$ of NAA and $50 \mu \mathrm{g} \mathrm{L}^{-1}$ of AE $(2.75 \mathrm{~mm}$ on average) (Table 4, Figure 5A).
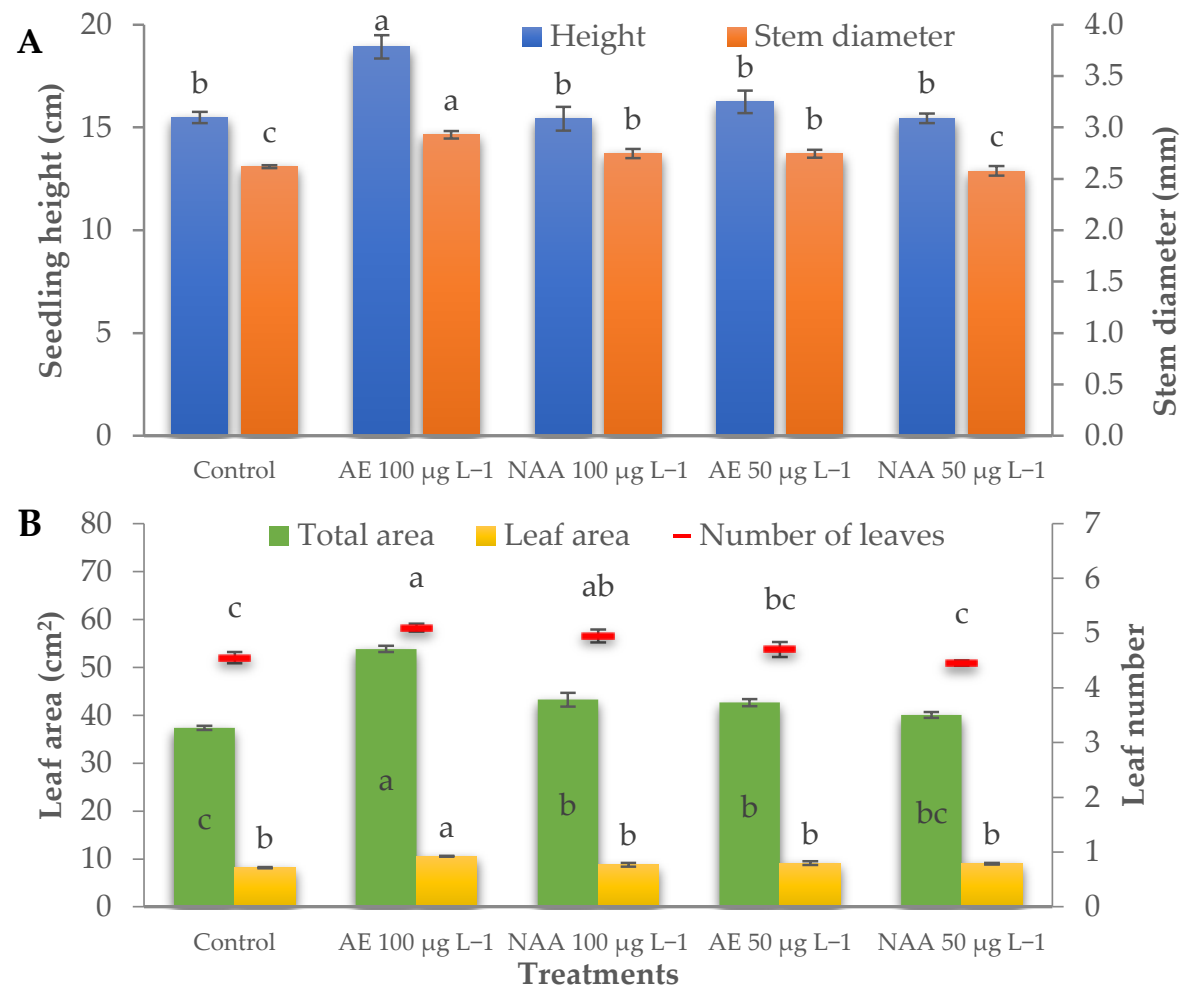

Figure 5. Effect of different doses $\left(50 \mu \mathrm{g} \mathrm{L}^{-1}\right.$ or $\left.100 \mu \mathrm{g} \mathrm{L}^{-1}\right)$ of natural (AE-algae extract from Ecklonia maxima) and synthetic (NAA) exogenous auxins on seedling height and stem diameter (A), and on total seedling area, leaf area, and leaf number (B) of tomato transplants (bars represent standard errors of the means; points or bars of the same color with different letters are significantly different at $p<0.05$ according to the Tukey test). 
Table 4. Effect of different doses $\left(50 \mu \mathrm{g} \mathrm{L}^{-1}\right.$ or $\left.100 \mu \mathrm{g} \mathrm{L}^{-1}\right)$ of natural (AE-algae extract from Ecklonia maxima) and synthetic (NAA) exogenous auxins on morphological parameters and chromatic characteristics of tomato transplants.

\begin{tabular}{|c|c|c|c|c|c|c|c|c|c|}
\hline Treatments & $\begin{array}{l}\text { Height } \\
\text { (cm) }\end{array}$ & $\begin{array}{c}\text { Stem } \\
\text { Diameter } \\
(\mathrm{mm})\end{array}$ & $\begin{array}{l}\text { Number } \\
\text { of Leaves }\end{array}$ & $\begin{array}{c}\text { Leaf Area } \\
\quad\left(\mathrm{cm}^{2}\right. \\
\text { seedling }\end{array}$ & $\begin{array}{c}\text { Leaf Area } \\
\left(\mathrm{cm}^{2}\right. \\
\left.\text { leaf }^{-1}\right)\end{array}$ & $\begin{array}{c}\operatorname{SLA}\left(\mathrm{cm}^{2}\right. \\
\left.\mathrm{g} \mathrm{dw}^{-1}\right)\end{array}$ & $\mathbf{L}^{*}$ & Chroma & Hue \\
\hline Control & $\mathrm{z} 15.5 \mathrm{~b}$ & $2.62 c$ & $4.55 c$ & $37.3 \mathrm{c}$ & $8.2 \mathrm{~b}$ & $567.2 \mathrm{~b}$ & $44.6 \mathrm{~b}$ & 30.5 & $126.6 \mathrm{ab}$ \\
\hline $\mathrm{AE} 100 \mu \mathrm{g} \mathrm{L}^{-1}$ & $18.9 \mathrm{a}$ & $2.93 \mathrm{a}$ & $5.10 \mathrm{a}$ & $53.8 \mathrm{a}$ & $10.6 \mathrm{a}$ & $644.9 \mathrm{a}$ & $44.5 \mathrm{~b}$ & 31.6 & $126.8 \mathrm{a}$ \\
\hline NAA $100 \mu \mathrm{g} \mathrm{L}^{-1}$ & $15.4 \mathrm{~b}$ & $2.75 \mathrm{~b}$ & $4.95 \mathrm{ab}$ & $43.3 \mathrm{~b}$ & $8.8 \mathrm{~b}$ & $678.7 \mathrm{a}$ & $45.3 \mathrm{ab}$ & 32.2 & $126.3 \mathrm{ac}$ \\
\hline AE $50 \mu \mathrm{g} \mathrm{L}^{-1}$ & $16.3 \mathrm{~b}$ & $2.74 \mathrm{~b}$ & $4.70 \mathrm{bc}$ & $42.6 \mathrm{~b}$ & $9.1 \mathrm{~b}$ & $569.0 \mathrm{~b}$ & $45.7 \mathrm{ab}$ & 31.9 & $125.7 \mathrm{bc}$ \\
\hline NAA $50 \mu \mathrm{g} \mathrm{L}^{-1}$ & $15.4 \mathrm{~b}$ & $2.58 \mathrm{c}$ & $4.45 c$ & $40.1 \mathrm{bc}$ & $9.0 \mathrm{~b}$ & $591.5 \mathrm{~b}$ & $46.3 \mathrm{a}$ & 31.9 & $125.7 \mathrm{c}$ \\
\hline Significance $\mathrm{x}$ & $* * *$ & $* * *$ & $* *$ & $* * *$ & $* * *$ & $* * *$ & $*$ & ns & $*$ \\
\hline
\end{tabular}

${ }^{\mathrm{z}}$ Each value is the mean of 4 replicated samples of 25 seedlings each. Data within a column followed by the same letters do not differ significantly at $p \leq 0.05$ according to Tukey test. ${ }^{\times}$Significance: $\mathrm{ns}=$ not significant; * significant at $p<0.05 ; * *$ significant at $p<0.01 ;{ }^{* * *}$ significant at $p<0.001$.

A significantly higher number of leaves than the control (4.55) were found in the seedlings treated with $100 \mu \mathrm{g} \mathrm{L}^{-1}$ of AE or NAA (5.10 and 4.95 leaves seedling ${ }^{-1}$ for natural and synthetic auxins, respectively) (Table 4, Figure 5B). The leaf area of the control seedlings was $8.2 \mathrm{~cm}^{2}$ leaf $^{-1}$ and $37.3 \mathrm{~cm}^{2}$ seedling ${ }^{-1}$. Treatments were effective in increasing the average leaf area only using $100 \mu \mathrm{g} \mathrm{L} \mathrm{L}^{-1}$ of natural auxins (AE), which determined the greatest leaf area per seedling $\left(53.8 \mathrm{~cm}^{2}\right.$ seedling $\left.{ }^{-1}\right)$. Nevertheless, a significant increase in total leaf area was also recorded with $50 \mu \mathrm{g} \mathrm{L}^{-1}$ of AE and $100 \mu \mathrm{g} \mathrm{L}{ }^{-1}$ of NAA $\left(42.98 \mathrm{~cm}^{2}\right.$ seedling ${ }^{-1}$ on average) (Table 4, Figure 5B). The treatments with $100 \mu \mathrm{g} \mathrm{L}^{-1}$ of auxins (both $\mathrm{AE}$ and NAA) recorded an increase in the specific leaf area by $16.7 \%$ on average, compared to the control seedlings $\left(567.2 \mathrm{~cm}^{2} \mathrm{~g} \mathrm{dw}^{-1}\right)$.

The chromatic characteristics of the tomato leaves ( $\mathrm{L}^{*}$, chroma, and hue) were slightly influenced by the treatments. The leaf color of tomato seedlings treated with $50 \mu \mathrm{g} \mathrm{L}^{-1}$ of NAA was lighter and less greenish (lower hue angle) than the control seedlings. No significant difference was recorded with regards to chroma (Table 4).

Total fresh weight ( $\mathrm{fw}$ ) was $2.05 \mathrm{~g} \mathrm{fw}$ seedling ${ }^{-1}$ in the control seedlings, which significantly increased by $6.4 \%$ in the tomato seedlings treated with NAA $\left(2.18 \mathrm{~g}\right.$ fw seedling ${ }^{-1}$ on average). A further increase was recorded when treating seedlings with natural auxins, especially with $100 \mu \mathrm{g} \mathrm{L}{ }^{-1} \mathrm{AE}\left(2.71 \mathrm{~g}\right.$ fw seedling ${ }^{-1} ;+32.1 \%$ than control) (Table 5 , Figure 6). The main part of the fresh biomass was represented by the stem and the leaves, which resulted in being significantly heavier than the control in the treated seedling, especially those treated with $100 \mu \mathrm{g} \mathrm{L}^{-1} \mathrm{AE}(+33.0 \%$ and $+51.7 \%$ compared to control for leaf and stem fresh weight, respectively). The seedlings treated with NAA recorded a reduction of root fresh weight compared to control, which was more severe as increasing NAA concentration $(-22.5 \%$ and $-34.4 \%$ for 50 and $100 \mu \mathrm{g} \mathrm{L}-1$ NAA, respectively) (Table 5 ).

Table 5. Effect of different doses $\left(50 \mu \mathrm{g} \mathrm{L}^{-1}\right.$ or $100 \mu \mathrm{g} \mathrm{L}^{-1}$ ) of natural (AE-algae extract from Ecklonia maxima) and synthetic (NAA) exogenous auxins on the fresh and dry weight of tomato seedlings.

\begin{tabular}{|c|c|c|c|c|c|c|c|c|c|c|c|}
\hline \multirow{2}{*}{ Treatments } & \multicolumn{5}{|c|}{ Fresh Weight (g seedling ${ }^{-1}$ ) } & \multicolumn{5}{|c|}{ Dry Weight (mg seedling ${ }^{-1}$ ) } & \multirow{2}{*}{ Dry Matter \% } \\
\hline & Total & Leaves & Stem & Root & Shoot/Root & Total & Leaves & Stem & Root & Shoot/Root & \\
\hline Control & $\mathrm{z} 2.05 \mathrm{~d}$ & $0.67 \mathrm{c}$ & $0.92 \mathrm{c}$ & $0.45 \mathrm{a}$ & $3.5 \mathrm{~d}$ & $146.8 \mathrm{c}$ & $65.8 \mathrm{c}$ & $48.3 \mathrm{~d}$ & $32.7 \mathrm{a}$ & $3.5 \mathrm{c}$ & $7.2 \mathrm{a}$ \\
\hline $\mathrm{AE} 100 \mu \mathrm{g} \mathrm{L}^{-1}$ & $2.71 \mathrm{a}$ & $0.90 \mathrm{a}$ & $1.40 \mathrm{a}$ & $0.41 \mathrm{a}$ & $5.6 \mathrm{~b}$ & $185.4 \mathrm{a}$ & $83.5 \mathrm{a}$ & $71.3 \mathrm{a}$ & $30.7 \mathrm{a}$ & $5.1 \mathrm{a}$ & $6.8 \mathrm{a}$ \\
\hline NAA $100 \mu \mathrm{g} \mathrm{L}^{-1}$ & $2.19 \mathrm{c}$ & $0.78 \mathrm{~b}$ & $1.12 \mathrm{~b}$ & $0.30 \mathrm{c}$ & $6.4 \mathrm{a}$ & $138.4 \mathrm{~d}$ & $63.8 \mathrm{c}$ & $50.0 \mathrm{~cd}$ & $24.7 \mathrm{~b}$ & $4.7 \mathrm{ab}$ & $6.3 \mathrm{~b}$ \\
\hline $\mathrm{AE} 50 \mu \mathrm{g} \mathrm{L}^{-1}$ & $2.27 \mathrm{~b}$ & $0.74 \mathrm{~b}$ & $1.10 \mathrm{~b}$ & $0.43 \mathrm{a}$ & $4.3 \mathrm{c}$ & $161.8 \mathrm{~b}$ & $75.0 \mathrm{~b}$ & $55.5 \mathrm{~b}$ & $31.3 \mathrm{a}$ & $4.2 \mathrm{~b}$ & $7.1 \mathrm{a}$ \\
\hline NAA $50 \mu \mathrm{g} \mathrm{L}^{-1}$ & $2.16 \mathrm{c}$ & $0.74 \mathrm{~b}$ & $1.07 \mathrm{~b}$ & $0.35 \mathrm{~b}$ & $5.2 \mathrm{~b}$ & $147.8 \mathrm{c}$ & $67.8 \mathrm{c}$ & $54.0 \mathrm{bc}$ & $26.0 \mathrm{~b}$ & $4.7 \mathrm{ab}$ & $6.8 \mathrm{a}$ \\
\hline Significance ${ }^{\mathrm{x}}$ & $* * *$ & $* * *$ & $* * *$ & $* * *$ & $* * *$ & $* * *$ & $* * *$ & $* * *$ & $* * *$ & $* * *$ & $* * *$ \\
\hline
\end{tabular}

${ }^{\mathrm{z}}$ Each value is the mean of 4 replicated samples of 25 seedlings each. Data within a column followed by the same letters do not differ significantly at $p \leq 0.05$ according to Tukey test. ${ }^{\mathrm{x}}$ Significance: ${ }^{* * *}$ significant at $p<0.001$. All percentage data were subjected to angular transformation. 


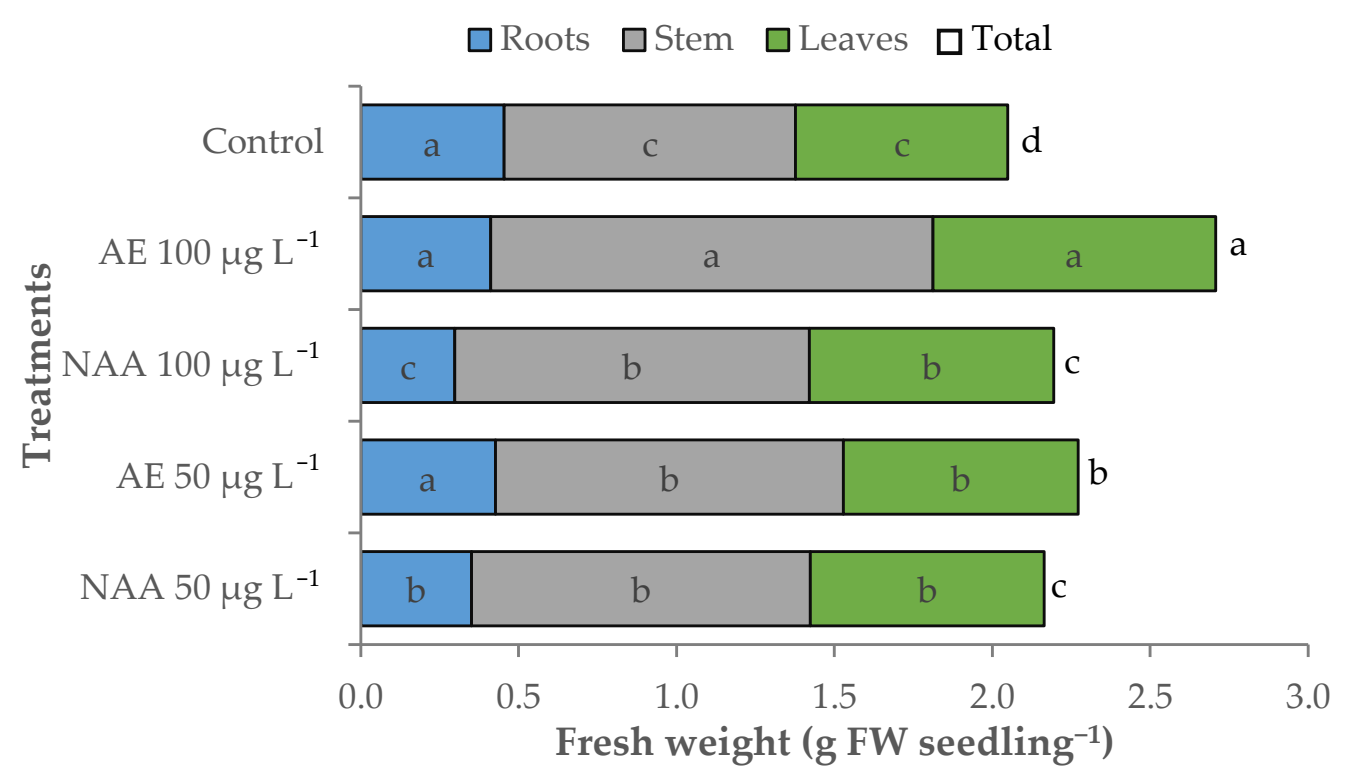

Figure 6. Effect of different doses $\left(50 \mu \mathrm{g} \mathrm{L}^{-1}\right.$ or $100 \mu \mathrm{g} \mathrm{L}^{-1}$ ) of natural (AE-algae extract from Ecklonia maxima) or synthetic (NAA) exogenous auxins on the total, root, stem, and leaves fresh biomass of tomato transplants (bars of the same color with different letters are significantly different at $p<0.05$ according to the Tukey test).

The modification of fresh biomass partitioning due to the experimental factors was shown by the shoot/root ratio of the fresh weight. The treated seedlings had a higher allocation of biomass in the shoots than control. This effect was higher with $100 \mu \mathrm{g} \mathrm{L}^{-1}$ than $50 \mu \mathrm{g} \mathrm{L}^{-1}$ and using NAA compared to the algae extract (Table 5).

The experimental factors also affected the dry weight $(\mathrm{dw})$ of tomato seedlings that increased significantly when natural auxins from E. maxima extracts were applied to the seedlings, while this decreased using $100 \mu \mathrm{g} \mathrm{L}^{-1}$ of NAA (Table 5, Figure 7). The plants treated with $100 \mu \mathrm{g} \mathrm{L}^{-1}$ of natural auxins (AE) had the highest total dry weight $\left(185.4 \mathrm{mg} \mathrm{dw}^{-1}\right.$ seedling ${ }^{-1}$ ) due to the highest dry biomass accumulated in the leaves (85.3 $\mathrm{mg}$ seedling $\left.{ }^{-1}\right)$ and stem $\left(71.3 \mathrm{mg}\right.$ seedling $\left.{ }^{-1}\right)$. The seedlings treated with $50 \mu \mathrm{g} \mathrm{L}{ }^{-1}$ AE had a lower dry biomass accumulation in the leaves and stem, but differed significantly from the control. The seedlings treated with NAA showed small or no significant differences with control seedlings regarding leaf and stem dry weight, but recorded the lowest dry biomass accumulation in the roots. Regarding the dry weight shoot/root ratio, all the treated seedlings showed a higher allocation of dry biomass in the shoots than in the control (3.5). The highest effect on dry biomass partitioning was recorded with $100 \mu \mathrm{g} \mathrm{L}^{-1}$ $\mathrm{AE}$ (5.1). A significant variation of dry matter percentage was found only in the seedlings treated with $100 \mu \mathrm{g} \mathrm{L}{ }^{-1}$ of NAA (6.3\%) (Table 5).

The leaves with higher stomatal conductance were those of the seedlings treated with $100 \mu \mathrm{g} \mathrm{L}^{-1}$ of natural (AE) or synthetic (NAA) auxins ( $+87.0 \%$ and $+54.3 \%$ than control, respectively) while the use of $50 \mu \mathrm{g} \mathrm{L}^{-1}$ of AE or NAA had no significant effect (Table 6).

The control seedlings produced $36.7 \mathrm{~g}$ of fresh biomass per liter of irrigation water (PWU); the treatments with both doses of synthetic auxin and with $50 \mu \mathrm{g} \mathrm{L}^{-1}$ of natural auxins applied through the Ecklonia maxima extract increased tomato seedling PWU by $23.6 \%$ on average, while the highest PWU value $\left(52.2 \mathrm{~g} \mathrm{fw} \mathrm{L}^{-1} \mathrm{H}_{2} \mathrm{O}\right)$ was recorded with $100 \mu \mathrm{g} \mathrm{L}^{-1}$ of natural auxins (AE) (+42.3\%) (Table 6).

The WUE of tomato seedlings was positively influenced to different extents by the source of auxins and their concentrations. WUE was $2.6 \mathrm{~g} \mathrm{dw} \mathrm{L} \mathrm{L}^{-1} \mathrm{H}_{2} \mathrm{O}$ in control seedlings, and increased by $19.6 \%$ in the seedlings treated with $50 \mu \mathrm{g} \mathrm{L}{ }^{-1}$ of AE and NAA (3.1, on average). Increasing the concentration of the Ecklonia maxima extract further increased WUE up to 3.6, whereas using $100 \mu \mathrm{g} \mathrm{L}^{-1}$ of NAA, WUE was 2.9. The NUE of control seedlings 
was $16.9 \mathrm{~g} \mathrm{dw}^{-1} \mathrm{~N}$. This parameter increased by $9.1 \%, 17.1 \%$, and $31.7 \%$, with $50 \mu \mathrm{g} \mathrm{L}^{-1}$ of NAA, 50 and $100 \mu \mathrm{g} \mathrm{L}^{-1}$ of natural auxins (AE), respectively (Table 6).

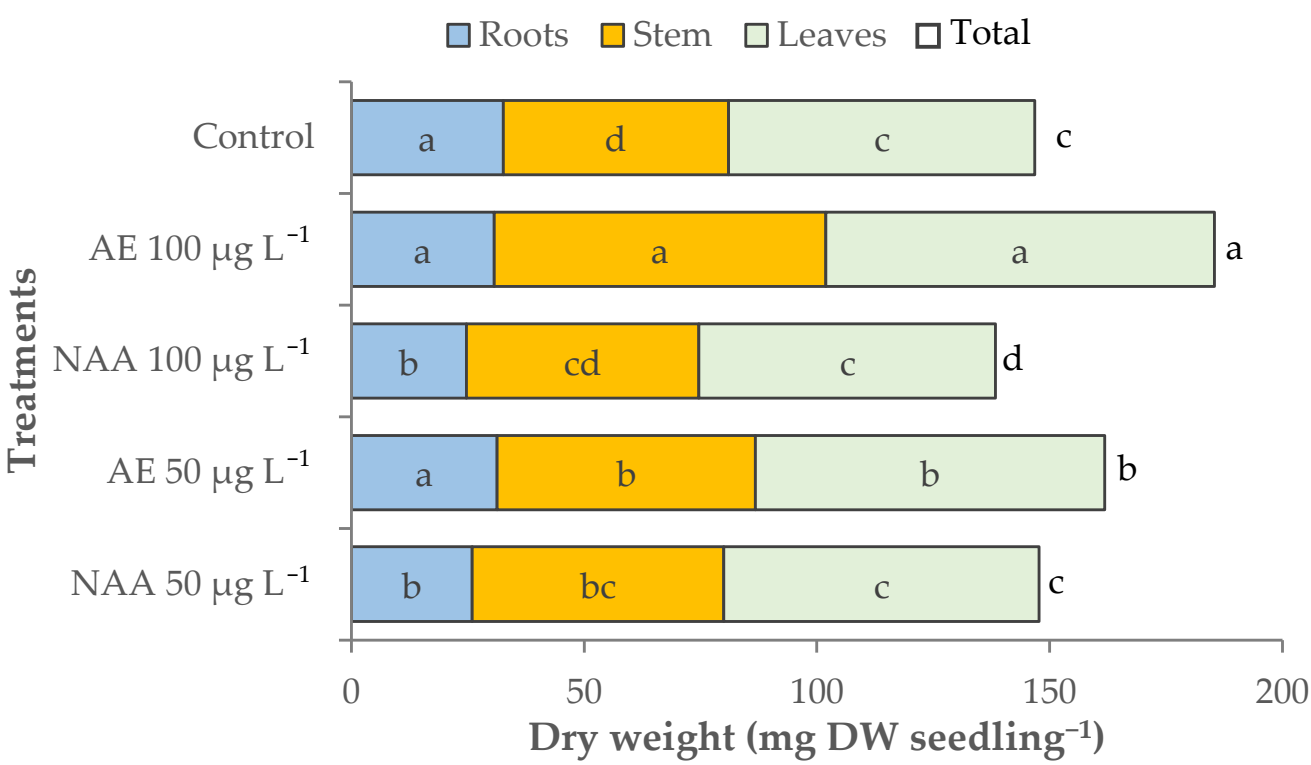

Figure 7. Effect of different doses $\left(50 \mu \mathrm{g} \mathrm{L}^{-1}\right.$ or $\left.100 \mu \mathrm{g} \mathrm{L}^{-1}\right)$ of natural (AE-algae extract from Ecklonia maxima) or synthetic (NAA) exogenous auxins on the total, root, stem, and leaves dry biomass of tomato transplants (bars of the same color with different letters are significantly different at $p<0.05$ according to the Tukey test).

Table 6. Effect of different doses $\left(50 \mu \mathrm{g} \mathrm{L}^{-1}\right.$ or $100 \mu \mathrm{g} \mathrm{L}{ }^{-1}$ ) of natural (AE-algae extract from Ecklonia maxima)) and synthetic (NAA) exogenous auxin on stomatal conductance, plant water use (PWU), water-use efficiency (WUE), and nitrogen-use efficiency (NUE) of tomato seedlings.

\begin{tabular}{|c|c|c|c|c|}
\hline Treatments & $\begin{array}{c}\text { Stomatal } \\
\text { Conductance } \\
\left(\mathrm{mmol} \mathrm{m}^{2} \mathrm{~s}^{-1}\right)\end{array}$ & 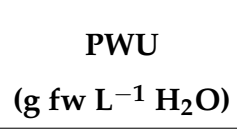 & $\begin{array}{c}\text { WUE } \\
\left(\mathrm{g} \mathrm{dw} \mathrm{L}^{-1} \mathrm{H}_{2} \mathrm{O}\right)\end{array}$ & $\begin{array}{c}\text { NUE } \\
\left(\mathrm{g} \mathrm{dw}^{-1} \mathrm{~N}\right)\end{array}$ \\
\hline Control & z 399.3 c & $36.7 \mathrm{c}$ & $2.6 \mathrm{~d}$ & $16.9 \mathrm{~d}$ \\
\hline $\mathrm{AE} 100 \mu \mathrm{g} \mathrm{L}^{-1}$ & 746.7 a & $52.2 \mathrm{a}$ & $3.6 \mathrm{a}$ & $22.3 \mathrm{a}$ \\
\hline NAA $100 \mu \mathrm{g} \mathrm{L}^{-1}$ & $616.0 \mathrm{~b}$ & $45.9 \mathrm{~b}$ & $2.9 \mathrm{c}$ & $16.1 \mathrm{~d}$ \\
\hline AE $50 \mu \mathrm{g} \mathrm{L}^{-1}$ & $494.0 \mathrm{c}$ & $44.9 \mathrm{~b}$ & $3.2 \mathrm{~b}$ & $19.8 \mathrm{~b}$ \\
\hline NAA $50 \mu \mathrm{g} \mathrm{L}^{-1}$ & $430.0 \mathrm{c}$ & $45.3 \mathrm{~b}$ & $3.1 \mathrm{~b}$ & $18.6 \mathrm{c}$ \\
\hline Significance ${ }^{\mathrm{x}}$ & $* * *$ & $* * *$ & $* * *$ & $* * *$ \\
\hline
\end{tabular}

${ }^{\mathrm{z}}$ Each value is the mean of 4 replicated samples of 25 seedlings each. Data within a column followed by the same letters do not differ significantly at $p \leq 0.05$ according to Tukey test. ${ }^{\times}$Significance: ${ }^{* * *}$ significant at $p<0.001$.

\subsection{Principal Component Analysis}

The principal component analysis revealed two principal components (PCs) with eigenvalues higher than 1.00, representing $77.49 \%$ and $15.90 \%$ of the total variance, respectively, and combined could represent the initial twenty-four variables, explaining $93.39 \%$ of the total variance (Table 7). PC1 was mainly related to stem diameter, leaf, stem, and root fresh weight (fw), shoot/root (S/R) fw, total, leaf and stem dry weight (dw), shoot/root $(\mathrm{S} / \mathrm{R}) \mathrm{dw}$, dry matter percentage, leaf number, plant and leaf area, specific leaf area (SLA), water-use efficiency (WUE), plant water use (PWU), L*, chroma, and hue angle; PC2 was related to total fresh weight and root dry weight (Table 7). The projection of the original variables on the plane of the two PCs displayed in the plot of loadings (Figure 8A) illustrates such relationships. 
Table 7. Correlation of variables to the factors of the principal components analysis (PCA) based on factor loadings.

\begin{tabular}{ccc}
\hline Variable & PC1 & PC2 \\
\hline Height & -0.664 & 0.567 \\
Stem diameter & $\mathbf{0 . 9 5 0}$ & 0.263 \\
Total fresh weight & -0.442 & $\mathbf{0 . 8 8 0}$ \\
Root fresh weight & $\mathbf{0 . 9 1 2}$ & 0.405 \\
Stem fresh weight & $\mathbf{- 0 . 9 7 5}$ & 0.133 \\
Leaf fresh weight & $\mathbf{- 0 . 9 5 0}$ & 0.040 \\
Shoot/Root fw & $\mathbf{0 . 8 0 7}$ & 0.454 \\
Total dry weight & $\mathbf{- 0 . 9 2 7}$ & 0.368 \\
Root dry weight & -0.128 & $\mathbf{0 . 9 6 3}$ \\
Stem dry weight & $\mathbf{- 0 . 9 8 1}$ & 0.147 \\
Leaf dry weight & $\mathbf{- 0 . 9 5 4}$ & 0.269 \\
Shoot/Root dw & $\mathbf{0 . 9 3 1}$ & 0.104 \\
Dry matter \% & $\mathbf{- 0 . 9 8 8}$ & -0.095 \\
Leaf number & $\mathbf{0 . 9 0 1}$ & 0.408 \\
Plant area & $\mathbf{0 . 8 6 1}$ & 0.505 \\
Leaf area & $\mathbf{0 . 7 8 7}$ & 0.600 \\
SLA & $\mathbf{0 . 9 7 8}$ & 0.171 \\
Stomatal conductance & $\mathbf{0 . 6 4 4}$ & -0.357 \\
WUE & $\mathbf{- 0 . 7 4 1}$ & 0.594 \\
PWU & $\mathbf{0 . 7 9 1}$ & 0.536 \\
NUE & -0.668 & 0.627 \\
L* & $\mathbf{0 . 9 7 1}$ & 0.047 \\
Chroma & $\mathbf{0 . 9 8 7}$ & -0.023 \\
Hue & $\mathbf{- 0 . 9 6 2}$ & 0.183 \\
\hline
\end{tabular}
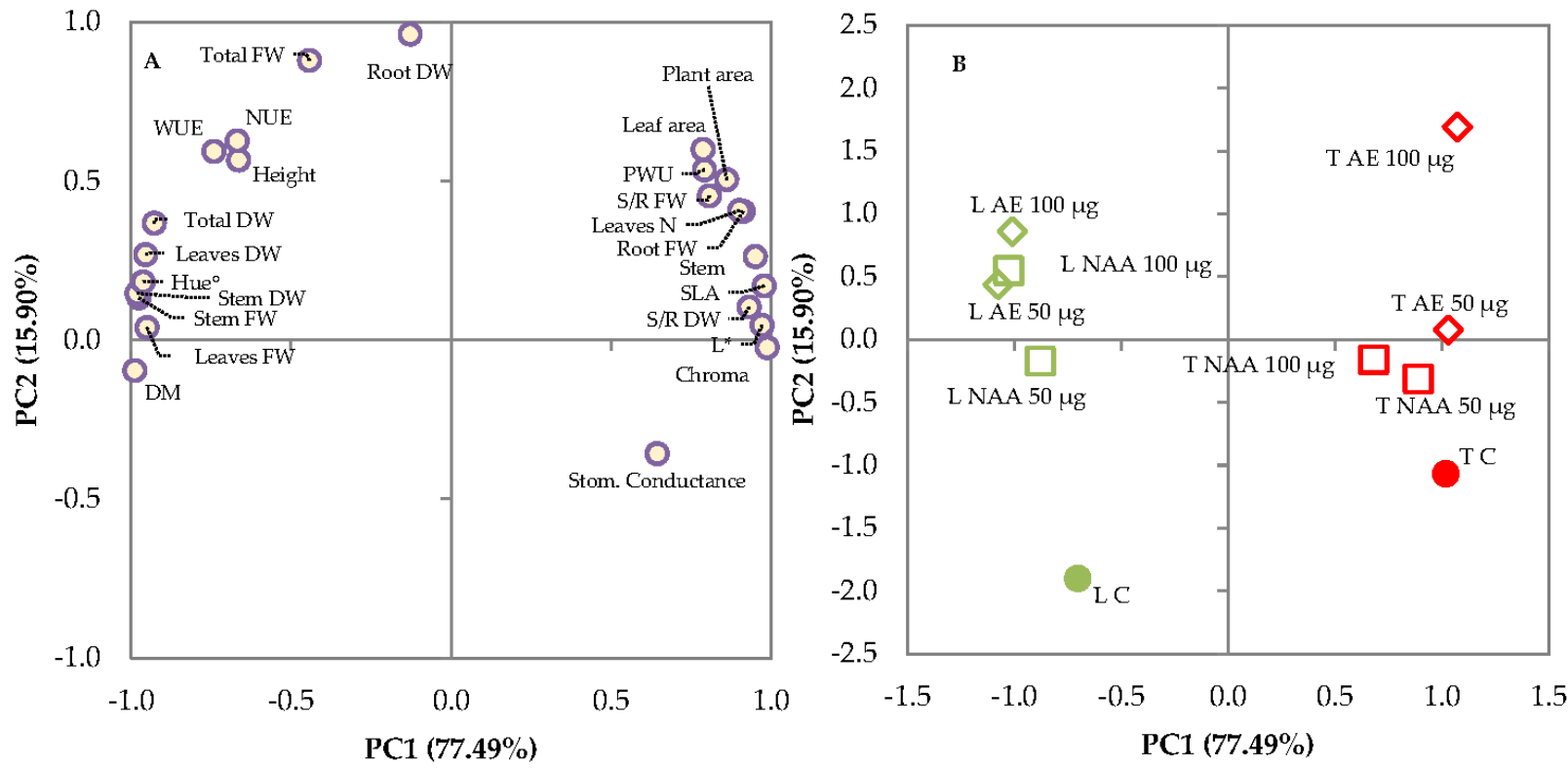

Figure 8. Plots of (A) loadings (morphophysiological characteristics of lettuce and tomato seedlings) and (B) scores (trials) formed by the two principal components from the principal component analysis (PCA). L C: untreated lettuce seedlings; L AE $100 \mu \mathrm{g}$ and L AE $50 \mu$ g lettuce seedlings treated with $100 \mu \mathrm{g} \mathrm{L}^{-1}$ and $50 \mu \mathrm{g} \mathrm{L}^{-1}$ of natural auxins from Ecklonia maxima extract, respectively; L NAA $100 \mu \mathrm{g}$ and L NAA $50 \mu \mathrm{g}$ lettuce seedlings treated with $100 \mu \mathrm{g} \mathrm{L^{-1 }}$ and $50 \mu \mathrm{g} \mathrm{L}{ }^{-1}$ of synthetic auxins (1-Naphthaleneacetic acid), respectively; T C: untreated tomato seedlings; T AE $100 \mu \mathrm{g}$ and T AE $50 \mu \mathrm{g}$ tomato seedlings treated with $100 \mu \mathrm{g} \mathrm{L}^{-1}$ and $50 \mu \mathrm{g} \mathrm{L}^{-1}$ of natural auxins from Ecklonia maxima extract, respectively; T NAA $100 \mu \mathrm{g}$ and T NAA $50 \mu \mathrm{g}$ tomato seedlings treated with $100 \mu \mathrm{g} \mathrm{L}{ }^{-1}$ and $50 \mu \mathrm{g} \mathrm{L}^{-1}$ of synthetic auxins (1-Naphthaleneacetic acid), respectively. 
The differentiation of the treatments with the E. maxima biostimulant or NAA to lettuce and tomato seedlings is shown in the plot of scores (Figure 8B), where two main clusters (lettuce and tomato transplants) could be visibly distinguished. The scores of lettuce seedlings were located in the negative part of the PC1 axis, whereas tomato seedlings were located in the positive part of the PC1 axis; the untreated lettuce seedlings were located in the third quadrant $(-,-)$ together with those treated with $50 \mu \mathrm{g} \mathrm{L}{ }^{-1}$ of NAA, whereas the untreated tomato seedlings were located in the fourth quadrant $(+,-)$ together with those treated with both doses of NAA. The lettuce seedlings treated with natural auxins from $E$. maxima extract (AE) or with $100 \mu \mathrm{g} \mathrm{L}^{-1}$ of NAA were located in the second quadrant $(-,+)$ whereas the tomato seedlings treated with E. maxima extract (AE) had higher and positive PC2 values, and were located in the first quadrant $(+,+)$.

Thus, lettuce and tomato seedlings showed a different response to the E. maxima extract or NAA supplemented through the irrigation water. The scores of treated lettuce seedlings increased their PC2 by increasing auxin concentration, but this was seen to a greater extent when using the seaweed extract as a source of natural auxins. Tomato seedlings were less influenced by NAA, but showed a higher sensitivity to the treatments with $100 \mu \mathrm{g} \mathrm{L}^{-1}$ of natural auxins from the E. maxima extract. Combining the data from the plot of loadings and scores, it can be concluded that the treatment with natural or synthetic auxins influenced the lettuce and tomato seedlings in different ways.

\section{Discussion}

In this work, we investigated methods of enhancing the growth of lettuce and tomato seedlings and producing vegetable transplants with good quality characteristics, by supplementing a commercial biostimulant produced from the seaweed Eclonia maxima that can be considered a source of natural auxins, and other plant growth promoters. We also supplied the seedlings with an equal concentration of synthetic auxin (NAA) to elucidate if it can exert similar effects on seedling growth.

It is well known that not all species respond to the same amount and type of auxins, and that the response can be very different even among plants of the same species [44]. The different responses of the two vegetable species to the auxin sources (natural auxins contained in the commercial Ecklonia maxima extract, or NAA) can depend on the auxin influx and efflux carriers. Some specialized carriers mediate the auxin's polar transport: incoming carrier proteins of the family AUX1/LAX and outgoing carrier protein of the PIN family. Researchers have proven that the auxin influx carriers (AUX/LAX family) facilitate the uptake of the natural auxin IAA and the synthetic auxin 2,4-dichlorophenoxyacetic acid (2,4-D), but not the synthetic auxin NAA [45-50]. The transport specificities and locations of AUX/LAX family members may contribute to the differences in auxin response. Although all the examined PIN proteins in Arabidopsis transport IAA, PIN family members differ in their ability to transport other auxinic compounds [51-53]. All this involves differences in responses to varying auxinic compounds within the same species and among different species [54].

The effects of exogenous auxins on morphological parameters could be contrasting. It has been reported that high concentrations of auxin in maize roots produced shorter plants [40], while Patel et al. [55] revealed that the application of NAA to tomato plants increased their height. In our work, we found the tallest tomato seedlings with the largest stem diameter in the seedlings treated with $100 \mu \mathrm{g} \mathrm{L}^{-1}$ of natural auxins from Ecklonia maxima extract. Lettuce seedlings reacted differently to the treatments, with a significant increase in the height and stem diameter with all the treatments with exogenous auxins. According to Immanem et al. [56], auxins and cytokinins show distinct but interconnected stimulation to cambium activity. It cannot be excluded that the presence of traces of cytokinins in the commercial biostimulant used in this experiment may have led to the formation of a more robust stem.

Leaf number is dependent on shoot meristem size and leaf initiation rate [57]. Furthermore, leaf size is determined by the rate and duration of cell division and expansion in the 
process of development [58]. The rate of leaf emission and their expansion can influence the time needed for producing transplants in vegetable nurseries and their quality. The exogenous supply of auxins was effective in increasing leaf number, irrespective of auxin source and dose in lettuce seedlings, or only with $100 \mu \mathrm{g} \mathrm{L}^{-1}$ of both auxin sources in tomato seedlings. Even leaf size and total leaf area were affected by the auxin treatments, but auxin source and concentration determined the effects with different strengths on lettuce and tomato seedlings. The plant hormone auxin plays an important role in promoting leaflet formation and blade outgrowth [59], whether it comes from plant biosynthesis or exogenous application [60-63]. This process also involves other hormones. The sites of leaf primordium initiation are determined in the meristem by auxin peaks and by auxininduced repression of the so-called KNOXI gene [64]; this repression allows gibberellin effects to be enhanced which, in turn, eventually leads to leaflet growth and differentiation. Nevertheless, not every exogenous application acts in the same way: the phenotypic manifestation depends on the origin of the auxin and plant species.

The plants regulate gas exchange and leaf temperature $[65,66]$ through the aperture of stomata which respond to hydraulic and chemical signals [67]. Auxins can determine the stomatal opening and extrusion of $\mathrm{H}^{+}$by activating plasma membrane $\mathrm{H}^{+}$-ATPase and inwardly and outwardly rectifying $\mathrm{K}^{+}$currents [68]. The lettuce and tomato seedlings showed a similar response to the exogenous auxin treatments with regard to stomatal conductance. We recorded that, in lettuce seedlings, the highest concentration of both natural and synthetic auxins determined an increase in stomatal conductance (by 2.7-fold, on average) compared to the control. Similarly, tomato seedlings had a stomatal conductance significantly higher than the control with $100 \mu \mathrm{g} \mathrm{L}^{-1}$ of auxins, but to a greater extent with the use of Ecklonia maxima extract that also contained traces of cytokinins. It is reported that stomatal responses to exogenously applied cytokinins are also dependent on plant species and the concentration and type of cytokinin used $[67,69]$. The increase in stomatal conductance can be related to increases in PUE and WUE [70,71]. This was particularly evident in tomato seedlings, where the treatments with auxins determined the increase in the fresh and dry weight per unit of water consumed compared to the control.

The adaptive responses of the plant to nitrogen involve countless molecules such as peptides, microRNAs, and plant hormones [72-74] that are transported long-distance to mediate organ-to-organ communication. Among those molecules, plant hormones have a decisive role in controlling the uptake and transport of ions and in morphophysiological responses to nutrient cues. According to Dos Santos et al. [75], plant responses to nitrogen supply are dependent on auxin signaling, which can be coming from endogenous biosynthesis or exogenous sources. Zhang et al. [49] have shown that, on rice (Oryza sativa), the NUE quantitative trait locus is involved in auxin homeostasis. The promotion of auxin biosynthesis results in improved NUE. In our study, we found that the exogenous supplementation of auxins to tomato seedlings promoted the nitrogen-use efficiency, especially when using E. maxima extract containing natural auxins, while lettuce seedlings showed a significant increase in NUE only when using the higher concentration of the $E$. maxima extract.

Cellular auxin levels depend on the rate of anabolism, catabolism, transport, and conjugation at any given time in a tissue [76-78]. Ecklonia maxima extract also contains phenolic compounds that influence the metabolism and concentration of active forms of auxins in plants. Particularly, phenolic inhibitors of auxin-oxidase, such as phenolic compounds, chlorogenic acid, and rutin, have been shown to enhance auxin activities [79]. Some of these compounds act as alternative substrates for oxidative enzymes, and thus protect auxins from oxidative breakdown. Aremu et al. [15] stated that plants treated with Ecklonia maxima extract had more endogenous auxins. According to Wilson and Van Staden [80], some phenolics may protect auxins from decarboxylation, thereby enhancing the concentration of active forms of this hormone.

It was well documented that most biological processes are not regulated by a single hormone but rather by complex signaling networks controlled by multiple hormones or 
other signaling components. Auxins and cytokinins act in consort to control the formation of the embryonic root, root meristem size, root branching, vascular pattern, and shoot phyllotaxy [81-83]. Furthermore, the application of a high quantity of natural auxins induces the plant to increase the production of cytokinins for restoring the natural balance between phytohormones.

In our study, we found a lower effect of NAA compared to natural auxins from $E$. maxima extract, especially for tomato seedlings. The explanations may depend on what was previously mentioned about the protein carriers and on the additional presence of cytokine in the seaweed extract $[32,33]$. The greater effects of Ecklonia maxima treatments on tomato and lettuce seedlings could also be ascribed to the synergistic action of the auxins and all the other components of the biostimulant [18,33]. The biological mechanisms activated by seaweed extracts can be very intricate due to the various number of compounds naturally occurring or commercially added (micronutrients, sugars, and amino acids) that could potentially have a complementary effect on plant growth promotion [84]. Thus, the synergistic nature of the different compounds of a biostimulant solution makes it difficult to isolate the way of action of a single active component [85]. Moreover, the plant-growth regulators contained in the E. maxima extract cross-talk among them and could act synergistically or antagonistically on plant growth regulation and plant hormone homeostasis [86].

It is well established that plant roots use inorganic $\mathrm{N}$ forms (ammonium, nitrate), but they can also take up organic nitrogen compounds of low molecular mass, such as amino acids [87-89]. Amino acids play a fundamental role in plant protein synthesis and are translocated between different plant organs, both in the xylem and phloem. For most seaweeds, aspartic and glutamic acids together constitute a large part of the amino acid fraction [90]. Additionally, available amino acids in the substrate could promote mineral metabolism in general, such as the redistribution of nitrogen [88,91]. We found that tomato seedlings treated with the biostimulant produced from E. maxima (AE) resulted in a greater accumulation of biomass, and a higher content of dry matter, as if the plants had access to a source of organic nitrogen. A non-negligible quantity of 'organic substances', equal to $268 \mathrm{mg}$ and $134 \mathrm{mg}$, was indirectly supplied to every single plant with the supply of 100 and $50 \mu \mathrm{g} \mathrm{L}^{-1}$ of auxins from Basfoliar ${ }^{\circledR}$ Kelp SL. These organic substances also include oligoalginates obtained by depolymerization of alginates that promote the growth of different plants by enhancing nitrogen assimilation and basal metabolism [24,33]. Furthermore, enhanced soil conditions were also found when seaweed extract was applied to substrates, with the alginic acid action targeted at stimulating the bacterial decomposition of organic material [92]. Soluble alginates from seaweed extracts act as an aggregation facilitator among soil particles, thus resulting in increased nutrient uptake [17,92].

The different responses of lettuce and tomato seedlings to the treatments with the biostimulant produced from E. maxima (AE) or NAA were well summarized by the principal component analysis. Tomato showed to be mainly influenced by the E. maxima treatments, especially when supplementing a high dose, whereas lettuce seedlings were more positively affected by the increasing level of exogenous auxins but with greater growth-promoting effect using natural auxins from E. maxima extract (AE). The concentration of seaweed extracts can be a critical factor in determining their effectiveness [93]. Tomato plants showed inhibited root growth under high concentrations of auxins (1:100 seaweed extract:water) whereas a lower concentration (1:600) determined a stimulatory effect [94]. Thus, the differences in plant growth promotion of E. maxima extract on the tested species could be ascribed to the different responsiveness of lettuce and tomato seedlings to the doses used in this study.

\section{Conclusions}

The results showed that the supplementation of exogenous synthetic auxin (NAA) or an Ecklonia maxima extract containing natural auxins can have a growth-promoting effect on lettuce and tomato seedlings, and improve transplant production under nursery conditions. 
This effect was more evident on lettuce than tomato, which reacted differently to the source and concentration of exogenous auxins. The commercial biostimulant produced from Ecklonia maxima extracts improved seedling quality and promoted shoot and root growth more than the NAA used as a synthetic source of auxin; thus, the growth-promoting effects of the Ecklonia maxima extract could probably also be ascribed to the synergistic effect of the natural auxins and the other organic substances contained in the extract.

Further research may be valuable to elucidate the growth stimulatory effects of Ecklonia maxima extract, to explore the effect of this biostimulant on endogenous phytohormones such as gibberellins, and to investigate the potential of this compound alone or with other classical phytohormones under biotic and abiotic stress conditions.

Author Contributions: Conceptualization, A.M. (Alessandra Moncada), F.V. and A.M. (Alessandro Miceli); data curation, A.M. (Alessandra Moncada), F.V., A.E. and A.M. (Alessandro Miceli); formal analysis, A.M. (Alessandra Moncada), F.V., A.E. and A.M. (Alessandro Miceli); investigation, A.M. (Alessandra Moncada), F.V., A.E. and A.M. (Alessandro Miceli); methodology, A.M. (Alessandra Moncada), F.V. and A.M. (Alessandro Miceli); supervision, A.M. (Alessandro Miceli); validation, A.M. (Alessandra Moncada) and A.M. (Alessandro Miceli); visualization, F.V. and A.E.; writing-original draft, A.M. (Alessandra Moncada), F.V., A.E. and A.M. (Alessandro Miceli); writing-review and editing, A.M. (Alessandra Moncada), F.V. and A.M. (Alessandro Miceli). All authors have read and agreed to the published version of the manuscript.

Funding: This research received no external funding.

Institutional Review Board Statement: Not applicable.

Informed Consent Statement: Not applicable.

Data Availability Statement: The data presented in this study are available in tables and figures.

Conflicts of Interest: The authors declare no conflict of interest.

\section{References}

1. Nicola, S.; Cantliffe, D.J. Increasing cell size and reducing medium compression enhance lettuce transplant quality and field production. HortScience 1996, 31, 184-189. [CrossRef]

2. Iapichino, G.; Vetrano, F.; Moncada, A.; Fascella, S.; Incalcaterra, G. Effects of plastic mulch and floating cover on lettuce production in Sicily. Acta Hortic. 2012, 936, 491-494. [CrossRef]

3. Kubota, C.; McClure, M.A.; Kokalis-Burelle, N.; Bausher, M.G.; Rosskopf, E.N. Vegetable Grafting: History, Use, and Current Technology Status in North America. HortScience 2008, 43, 1664-1669. [CrossRef]

4. Caracciolo, G.; Moncada, A.; Prinzivalli, C.; D'Anna, F. Effects of planting dates on strawberry plug plant performance in Sicily. Acta Hortic. 2009, 842, 155-158. [CrossRef]

5. Swiader, J.M.; Ware, G.W.; McCollum, J.P. Producing Vegetable Crops Teacher's Manual; Interstate Publishers: Crete, IL, USA, 1992; ISBN 0813429048.

6. Herrera, F.; Castillo, J.E.; Chica, A.F.; López Bellido, L. Use of municipal solid waste compost (MSWC) as a growing medium in the nursery production of tomato plants. Bioresour. Technol. 2008, 99, 287-296. [CrossRef]

7. Russo, V.M. Biological amendment, fertilizer rate, and irrigation frequency for organic Bll pepper transplant production. HortScience 2006, 41, 1402-1407. [CrossRef]

8. McCall, D. Effect of supplementary light on tomato transplant growth, and the after-effects on yield. Sci. Hortic. 1992, 51, 65-70. [CrossRef]

9. Masson, J.; Tremblay, N.; Gosselin, A. Effects of nitrogen fertilization and HPS supplementary lighting on vegetable transplant production. II. Yield. J. Am. Soc. Hortic. Sci. 1991, 116, 599-602. [CrossRef]

10. Vetrano, F.; Miceli, C.; Angileri, V.; Frangipane, B.; Moncada, A.; Miceli, A. Effect of Bacterial Inoculum and Fertigation Management on Nursery and Field Production of Lettuce Plants. Agronomy 2020, 10, 1477. [CrossRef]

11. Moncada, A.; Miceli, A.; Vetrano, F. Use of plant growth-promoting rhizobacteria (PGPR) and organic fertilization for soilless cultivation of basil. Sci. Hortic. 2021, 275, 109733. [CrossRef]

12. du Jardin, P. Plant biostimulants: Definition, concept, main categories and regulation. Sci. Hortic. 2015, 196, 3-14. [CrossRef]

13. Singh, J.S.; Pandey, V.C.; Singh, D.P. Efficient soil microorganisms: A new dimension for sustainable agriculture and environmental development. Agric. Ecosyst. Environ. 2011, 140, 339-353. [CrossRef]

14. Zandi, P.; Basu, S.K. Role of Plant Growth-Promoting Rhizobacteria (PGPR) as BioFertilizers in Stabilizing Agricultural Ecosystems. In Organic Farming for Sustainable Agriculture; Springer: Cham, Switzerland, 2016; pp. 71-87. 
15. Aremu, A.O.; Masondo, N.A.; Rengasamy, K.R.R.; Amoo, S.O.; Gruz, J.; Bíba, O.; Šubrtová, M.; Pěnčík, A.; Novák, O.; Doležal, K.; et al. Physiological role of phenolic biostimulants isolated from brown seaweed Ecklonia maxima on plant growth and development. Planta 2015, 241, 1313-1324. [CrossRef]

16. Kavipriya, R.; Dhanalakshmi, P.K.; Jayashree, S.; Thangaraju, N. Seaweed extract as a biostimulant for legume crop, green gram. J. Ecobiotechnol. 2011, 3, 16-19.

17. Verkleij, F.N. Seaweed extracts in agriculture and horticulture: A review. Biol. Agric. Hortic. 1992, 8, 309-324. [CrossRef]

18. Sharma, H.S.S.; Fleming, C.; Selby, C.; Rao, J.R.; Martin, T. Plant biostimulants: A review on the processing of macroalgae and use of extracts for crop management to reduce abiotic and biotic stresses. J. Appl. Phycol. 2014, 26, 465-490. [CrossRef]

19. Papenfus, H.B.; Stirk, W.A.; Finnie, J.F.; Van Staden, J. Seasonal variation in the polyamines of Ecklonia maxima. Bot. Mar. 2012, 55, 539-546. [CrossRef]

20. Stirk, W.A.; Van Staden, J. Comparison of cytokinin-and auxin-like activity in some commercially used seaweed extracts. J. Appl. Phycol. 1996, 8, 503-508. [CrossRef]

21. Stirk, W.A.; Tarkowská, D.; Turečová, V.; Strnad, M.; van Staden, J. Abscisic acid, gibberellins and brassinosteroids in Kelpak ${ }^{\circledR}$, a commercial seaweed extract made from Ecklonia maxima. J. Appl. Phycol. 2014, 26, 561-567. [CrossRef]

22. Craigie, J.S. Seaweed extract stimuli in plant science and agriculture. J. Appl. Phycol. 2011, 23, 371-393. [CrossRef]

23. Khan, W.; Zhai, R.; Souleimanov, A.; Critchley, A.T.; Smith, D.L.; Prithiviraj, B. Commercial extract of Ascophyllum nodosum improves root colonization of alfalfa by its bacterial symbiont Sinorhizobium meliloti. Commun. Soil Sci. Plant. Anal. 2012, 43 , 2425-2436. [CrossRef]

24. González, A.; Castro, J.; Vera, J.; Moenne, A. Seaweed oligosaccharides stimulate plant growth by enhancing carbon and nitrogen assimilation, basal metabolism, and cell division. J. Plant Growth Regul. 2013, 32, 443-448. [CrossRef]

25. Mooney, P.A.; Van Staden, J. Effect of seaweed concentrate on the growth of wheat under condition of water fern. S. Afr. J. Sci. $1985,8,632-633$.

26. Featonby-Smith, B.C.; Van Staden, J. The effect of seaweed concentrate and fertilizer on growth and the endogenous cytokinin content of Phaseolus vulgaris. S. Afr. J. Bot. 1984, 3, 375-379. [CrossRef]

27. Crouch, I.J.; Van Staden, J. Evidence for the presence of plant growth regulators in commercial seaweed products. Plant. Growth Regul. 1993, 13, 21-29. [CrossRef]

28. Anderson, R.J.; Bolton, J.J.; Molloy, F.J.; Rotmann, K.W.G. Commercial seaweeds in southern Africa. In Proceedings of the 17th International Seaweed Symposium, Cape Town, South Africa, 28 January-2 February 2001; Oxford University Press: Oxford, UK, 2003; pp. 1-12.

29. Khan, W.; Rayirath, U.P.; Subramanian, S.; Jithesh, M.N.; Rayorath, P.; Hodges, D.M.; Critchley, A.T.; Craigie, J.S.; Norrie, J.; Prithiviraj, B. Seaweed Extracts as Biostimulants of Plant Growth and Development. J. Plant. Growth Regul. 2009, 28, 386-399. [CrossRef]

30. Kurepin, L.V.; Zaman, M.; Pharis, R.P. Phytohormonal basis for the plant growth promoting action of naturally occurring biostimulators. J. Sci. Food Agric. 2014, 94, 1715-1722. [CrossRef]

31. Papenfus, H.B.; Kulkarni, M.G.; Stirk, W.A.; Finnie, J.F.; Van Staden, J. Effect of a commercial seaweed extract (Kelpak $\left.{ }^{\circledR}\right)$ and polyamines on nutrient-deprived (N, P and K) okra seedlings. Sci. Hortic. 2013, 151, 142-146. [CrossRef]

32. Stirk, W.A.; Arthur, G.D.; Lourens, A.F.; Novák, O.; Strnad, M.; Staden, J. van Changes in cytokinin and auxin concentrations in seaweed concentrates when stored at an elevated temperature. J. Appl. Phycol. 2004, 16, 31-39. [CrossRef]

33. Sosnowski, J.; Jankowski, K.; Malinowska, E.; Truba, M. The effect of Ecklonia maxima extract on Medicago X Varia T. Martyn biomass. J. Soil Sci. Plant. Nutr. 2017, 17, 770-780. [CrossRef]

34. Compo Expert Basfoliar®Kelp SL. Available online: https://www.compo-expert.com/products/basfoliar-kelp-sl (accessed on 15 September 2021).

35. EL Boukhari, M.E.M.; Barakate, M.; Bouhia, Y.; Lyamlouli, K. Trends in Seaweed Extract Based Biostimulants: Manufacturing Process and Beneficial Effect on Soil-Plant Systems. Plants 2020, 9, 359. [CrossRef]

36. Ghaderiardakani, F.; Collas, E.; Damiano, D.K.; Tagg, K.; Graham, N.S.; Coates, J.C. Effects of green seaweed extract on Arabidopsis early development suggest roles for hormone signalling in plant responses to algal fertilisers. Sci. Rep. 2019, 9, 1983. [CrossRef]

37. Pitts, R.J.; Cernac, A.; Estelle, M. Auxin and ethylene promote root hair elongation in Arabidopsis. Plant. J. 1998, 16, 553-560. [CrossRef]

38. Zhao, Y. Essential Roles of Local Auxin Biosynthesis in Plant Development and in Adaptation to Environmental Changes. Annu. Rev. Plant. Biol. 2018, 69, 417-435. [CrossRef]

39. De Smet, I.; Lau, S.; Voß, U.; Vanneste, S.; Benjamins, R.; Rademacher, E.H.; Schlereth, A.; De Rybel, B.; Vassileva, V.; Grunewald, W.; et al. Bimodular auxin response controls organogenesis in Arabidopsis. Proc. Natl. Acad. Sci. USA 2010, 107, 2705-2710. [CrossRef]

40. Li, Z.; Zhang, X.; Zhao, Y.; Li, Y.; Zhang, G.; Peng, Z.; Zhang, J. Enhancing auxin accumulation in maize root tips improves root growth and dwarfs plant height. Plant. Biotechnol. J. 2018, 16, 86-99. [CrossRef]

41. Ko, D.; Helariutta, Y. Shoot-root communication in flowering plants. Curr. Biol. 2017, 27, R973-R978. [CrossRef]

42. Baligar, V.C.; Fageria, N.K. Nutrient Use Efficiency in Plants: An Overview. Nutr. Use Effic. Basics Adv. 2015, 32, 1-14. [CrossRef]

43. McGuire, R.G. Reporting of objective color measurements. HortScience 1992, 27, 1254-1255. [CrossRef] 
44. Cancino-García, V.J.; Ramírez-Prado, J.H.; De-la-Peña, C. Auxin perception in Agave is dependent on the species' Auxin Response Factors. Sci. Rep. 2020, 10, 3860. [CrossRef]

45. Maher, E.P.; Martindale, S.J.B. Mutants of Arabidopsis thaliana with altered responses to auxins and gravity. Biochem. Genet. 1980, 18, 1041-1053. [CrossRef]

46. Yamamoto, M.; Yamamoto, K.T. Differential effects of 1-naphthaleneacetic acid, indole-3-acetic acid and 2, 4-dichlorophenoxyacetic acid on the gravitropic response of roots in an auxin-resistant mutant of Arabidopsis, auxl. Plant. Cell Physiol. 1998, 39, 660-664. [CrossRef]

47. Marchant, A.; Kargul, J.; May, S.T.; Muller, P.; Delbarre, A.; Perrot-Rechenmann, C.; Bennett, M.J. AUX1 regulates root gravitropism in Arabidopsis by facilitating auxin uptake within root apical tissues. EMBO J. 1999, 18, 2066-2073. [CrossRef]

48. Swarup, R.; Kargul, J.; Marchant, A.; Zadik, D.; Rahman, A.; Mills, R.; Yemm, A.; May, S.; Williams, L.; Millner, P. Structurefunction analysis of the presumptive Arabidopsis auxin permease AUX1. Plant. Cell 2004, 16, 3069-3083. [CrossRef]

49. Zhang, S.; Zhu, L.; Shen, C.; Ji, Z.; Zhang, H.; Zhang, T.; Li, Y.; Yu, J.; Yang, N.; He, Y.; et al. Natural allelic variation in a modulator of auxin homeostasis improves grain yield and nitrogen use efficiency in rice. Plant. Cell 2021, 33, 566-580. [CrossRef]

50. Yang, Y.; Hammes, U.Z.; Taylor, C.G.; Schachtman, D.P.; Nielsen, E. High-affinity auxin transport by the AUX1 influx carrier protein. Curr. Biol. 2006, 16, 1123-1127. [CrossRef]

51. Yang, H.; Murphy, A.S. Functional expression and characterization of Arabidopsis ABCB, AUX 1 and PIN auxin transporters in Schizosaccharomyces pombe. Plant. J. 2009, 59, 179-191. [CrossRef]

52. Petrášek, J.; Mravec, J.; Bouchard, R.; Blakeslee, J.J.; Abas, M.; Seifertová, D.; Wiśniewska, J.; Tadele, Z.; Kubeš, M.; Čovanová, M. PIN proteins perform a rate-limiting function in cellular auxin efflux. Science 2006, 312, 914-918. [CrossRef] [PubMed]

53. Blakeslee, J.J.; Bandyopadhyay, A.; Lee, O.R.; Mravec, J.; Titapiwatanakun, B.; Sauer, M.; Makam, S.N.; Cheng, Y.; Bouchard, R.; Adamec, J. Interactions among PIN-FORMED and P-glycoprotein auxin transporters in Arabidopsis. Plant. Cell 2007, 19, 131-147. [CrossRef] [PubMed]

54. Enders, T.A.; Strader, L.C. Auxin activity: Past, present, and future. Am. J. Bot. 2015, 102, 180-196. [CrossRef] [PubMed]

55. Patel, J.S.; Sitapara, H.H.; Patel, K.A. Influence of plant growth regulators on growth, yield and quality of tomato and brinjal. Int J. For. Crop. Improv. 2012, 3, 116-118.

56. Immanen, J.; Nieminen, K.; Smolander, O.P.; Kojima, M.; Alonso Serra, J.; Koskinen, P.; Zhang, J.; Elo, A.; Mähönen, A.P.; Street, N.; et al. Cytokinin and Auxin Display Distinct but Interconnected Distribution and Signaling Profiles to Stimulate Cambial Activity. Curr. Biol. 2016, 26, 1990-1997. [CrossRef]

57. Huang, W.; Pitorre, D.; Poretska, O.; Marizzi, C.; Winter, N.; Poppenberger, B.; Sieberer, T. ALTERED MERISTEM PROGRAM1 suppresses ectopic stem cell niche formation in the shoot apical meristem in a largely cytokinin-independent manner. Plant. Physiol. 2015, 167, 1471-1486. [CrossRef]

58. Andriankaja, M.; Dhondt, S.; De Bodt, S.; Vanhaeren, H.; Coppens, F.; De Milde, L.; Mühlenbock, P.; Skirycz, A.; Gonzalez, N.; Beemster, G.T.S. Exit from proliferation during leaf development in Arabidopsis thaliana: A not-so-gradual process. Dev. Cell 2012, 22, 64-78. [CrossRef]

59. Gonzalez, N.; Vanhaeren, H.; Inzé, D. Leaf size control: Complex coordination of cell division and expansion. Trends Plant. Sci. 2012, 17, 332-340. [CrossRef]

60. DeMason, D.A.; Chawla, R. Roles for auxin during morphogenesis of the compound leaves of pea (Pisum sativum). Planta 2004, 218, 435-448. [CrossRef]

61. Wang, S.; Tiwari, S.B.; Hagen, G.; Guilfoyle, T.J. AUXIN RESPONSE FACTOR7 restores the expression of auxin-responsive genes in mutant Arabidopsis leaf mesophyll protoplasts. Plant. Cell 2005, 17, 1979-1993. [CrossRef]

62. Barkoulas, M.; Hay, A.; Kougioumoutzi, E.; Tsiantis, M. A developmental framework for dissected leaf formation in the Arabidopsis relative Cardamine hirsuta. Nat. Genet. 2008, 40, 1136-1141. [CrossRef]

63. Koenig, D.; Bayer, E.; Kang, J.; Kuhlemeier, C.; Sinha, N. Auxin patterns Solanum lycopersicum leaf morphogenesis. Development 2009, 136, 2997-3006. [CrossRef]

64. Blein, T.; Hasson, A.; Laufs, P. Leaf development: What it needs to be complex. Curr. Opin. Plant. Biol. 2010, 13, 75-82. [CrossRef]

65. Jones, D.L. Organic acids in the rhizosphere-a critical review. Plant. Soil 1998, 205, 25-44. [CrossRef]

66. Salleo, S.; Nardini, A.; Pitt, F.; Gullo, M.A. Lo Xylem cavitation and hydraulic control of stomatal conductance in laurel (Laurus nobilis L.). Plant. Cell Environ. 2000, 23, 71-79. [CrossRef]

67. Pospíšilová, J. Interaction of cytokinins and abscisic acid during regulation of stomatal opening in bean leaves. Photosynthetica 2003, 41, 49-56. [CrossRef]

68. Song, X.-G.; She, X.-P.; He, J.-M.; Huang, C.; Song, T. Cytokinin- and auxin-induced stomatal opening involves a decrease in levels of hydrogen peroxide in guard cells of Vicia faba. Funct. Plant. Biol. 2006, 33, 573. [CrossRef]

69. Acharya, B.R.; Assmann, S.M. Hormone interactions in stomatal function. Plant. Mol. Biol. 2009, 69, 451-462. [CrossRef]

70. Liu, F.; Jensen, C.R.; Shahanzari, A.; Andersen, M.N.; Jacobsen, S.-E. ABA regulated stomatal control and photosynthetic water use efficiency of potato (Solanum tuberosum L.) during progressive soil drying. Plant. Sci. 2005, 168, 831-836. [CrossRef]

71. Liu, F.; Shahnazari, A.; Andersen, M.N.; Jacobsen, S.-E.; Jensen, C.R. Physiological responses of potato (Solanum tuberosum L.) to partial root-zone drying: ABA signalling, leaf gas exchange, and water use efficiency. J. Exp. Bot. 2006, 57, 3727-3735. [CrossRef]

72. Okamoto, S.; Shinohara, H.; Mori, T.; Matsubayashi, Y.; Kawaguchi, M. Root-derived CLE glycopeptides control nodulation by direct binding to HAR1 receptor kinase. Nat. Commun. 2013, 4, 2191. [CrossRef] 
73. Tabata, R.; Sumida, K.; Yoshii, T.; Ohyama, K.; Shinohara, H.; Matsubayashi, Y. Perception of root-derived peptides by shoot LRR-RKs mediates systemic N-demand signaling. Science 2014, 346, 343-346. [CrossRef]

74. Nguyen, G.; Rothstein, S.; Spangenberg, G.; Kant, S. Role of microRNAs involved in plant response to nitrogen and phosphorous limiting conditions. Front. Plant. Sci. 2015, 6, 629. [CrossRef]

75. Dos Santos, L.C.N.; Gaion, L.A.; Pprado, R.M.; Barreto, R.F.; Carvalho, R.F. Low auxin sensitivity of diageotropica tomato mutant alters nitrogen deficiency response. An. Acad. Bras. Cienc. 2020, 92, e20190254. [CrossRef] [PubMed]

76. Peer, W.A.; Murphy, A.S. Flavonoids and auxin transport: Modulators or regulators? Trends Plant. Sci. 2007, 12, 556-563. [CrossRef] [PubMed]

77. De Klerk, G.-J.; Guan, H.; Huisman, P.; Marinova, S. Effects of phenolic compounds on adventitious root formation and oxidative decarboxylation of applied indoleacetic acid in Malus 'Jork 9'. Plant. Growth Regul. 2011, 63, 175-185. [CrossRef]

78. da Silva, J.A.T.; Dobránszki, J.; Ross, S. Phloroglucinol in plant tissue culture. Vitr. Cell. Dev. Biol. 2013, $49,116$.

79. Gaspar, T.; Kevers, C.; Penel, C.; Greppin, H.; Reid, D.M.; Thorpe, T.A. Plant hormones and plant growth regulators in plant tissue culture. Vitr. Cell. Dev. Biol. 1996, 32, 272-289. [CrossRef]

80. Wilson, P.J.; van Staden, J. Rhizocaline, rooting co-factors, and the concept of promoters and inhibitors of adventitious rooting-A review. Ann. Bot. 1990, 66, 479-490. [CrossRef]

81. Dello Ioio, R.; Nakamura, K.; Moubayidin, L.; Perilli, S.; Taniguchi, M.; Morita, M.T.; Aoyama, T.; Costantino, P.; Sabatini, S. A genetic framework for the control of cell division and differentiation in the root meristem. Science 2008, 322, 1380-1384. [CrossRef]

82. Besnard, F.; Refahi, Y.; Morin, V.; Marteaux, B.; Brunoud, G.; Chambrier, P.; Rozier, F.; Mirabet, V.; Legrand, J.; Lainé, S. Cytokinin signalling inhibitory fields provide robustness to phyllotaxis. Nature 2014, 505, 417-421. [CrossRef]

83. Bishopp, A.; Benková, E.; Helariutta, Y. Sending mixed messages: Auxin-cytokinin crosstalk in roots. Curr. Opin. Plant. Biol. 2011, 14, 10-16. [CrossRef]

84. Saa, S.; Olivos-Del Rio, A.; Castro, S.; Brown, P.H. Foliar application of microbial and plant based biostimulants increases growth and potassium uptake in almond (Prunus dulcis [Mill.] D. A. Webb). Front. Plant. Sci. 2015, 6, 87. [CrossRef]

85. Masondo, N.A.; Aremu, A.O.; Kulkarni, M.G.; Petřík, I.; Plačková, L.; Šubrtová, M.; Novák, O.; Grúz, J.; Doležal, K.; Strnad, M.; et al. Elucidating the role of Kelpak ${ }^{\circledR}$ on the growth, phytohormone composition, and phenolic acids in macronutrientstressed Ceratotheca triloba. J. Appl. Phycol. 2019, 31, 2687-2697. [CrossRef]

86. Han, Y.Y.; Li, A.X.; Li, F.; Zhao, M.R.; Wang, W. Characterization of a wheat (Triticum aestivum L.) expansin gene, TaEXPB23, involved in the abiotic stress response and phytohormone regulation. Plant. Physiol. Biochem. 2012, 54, 49-58. [CrossRef]

87. Chapin, F.S.; Moilanen, L.; Kielland, K. Preferential use of organic nitrogen for growth by a non-mycorrhizal arctic sedge. Nature 1993, 361, 150-153. [CrossRef]

88. Kielland, K. Amino acid absorption by arctic plants: Implications for plant nutrition and nitrogen cycling. Ecology 1994, 75, 2373-2383. [CrossRef]

89. Näsholm, T.; Ekblad, A.; Nordin, A.; Giesler, R.; Högberg, M.; Högberg, P. Boreal forest plants take up organic nitrogen. Nature 1998, 392, 914-916. [CrossRef]

90. Gressler, V.; Yokoya, N.S.; Fujii, M.T.; Colepicolo, P.; Mancini Filho, J.; Torres, R.P.; Pinto, E. Lipid, fatty acid, protein, amino acid and ash contents in four Brazilian red algae species. Food Chem. 2010, 120, 585-590. [CrossRef]

91. Dakora, F.D.; Phillips, D.A. Root exudates as mediators of mineral acquisition in low-nutrient environments. In Food Security in Nutrient-Stressed Environments: Exploiting Plants' Genetic Capabilities; Springer Science \& Business Media: New York, NY, USA, 2002; pp. 201-213.

92. Kaur, I. Seaweeds: Soil Health Boosters for Sustainable Agriculture. In Soil Health; Giri, B., Varma, A., Eds.; Springer: Cham, Switzerland, 2020; pp. 163-182.

93. Miceli, A.; Vetrano, F.; Moncada, A. Influence of Ecklonia maxima Extracts on Growth, Yield, and Postharvest Quality of Hydroponic Leaf Lettuce. Horticulturae 2021, 7, 440. [CrossRef]

94. Panda, D.; Pramanik, K.; Nayak, B.R. Use of Sea Weed Extracts as Plant Growth Regulators for Sustainable Agriculture. Int. J. Bio-Resour. Stress Manag. 2012, 3, 404-411. 